\title{
Brain Vascular Imaging Techniques
}

\author{
Bàrbara Laviña \\ Department of Immunology, Genetics and Pathology, Rudbeck Laboratory, Uppsala University, \\ 75185 Uppsala, Sweden; barbara.lavina-siemsen@igp.uu.se; Tel.: +46-018-471-4504
}

Academic Editor: Michael Henein

Received: 24 October 2016; Accepted: 26 December 2016; Published: 30 December 2016

\begin{abstract}
Recent major improvements in a number of imaging techniques now allow for the study of the brain in ways that could not be considered previously. Researchers today have well-developed tools to specifically examine the dynamic nature of the blood vessels in the brain during development and adulthood; as well as to observe the vascular responses in disease situations in vivo. This review offers a concise summary and brief historical reference of different imaging techniques and how these tools can be applied to study the brain vasculature and the blood-brain barrier integrity in both healthy and disease states. Moreover, it offers an overview on available transgenic animal models to study vascular biology and a description of useful online brain atlases.
\end{abstract}

Keywords: brain vascular disorders; imaging; vascular biology; brain atlas; animal models; molecular imaging; computed tomography (CT); positron emission tomography (PET); magnetic resonance angiography (MRI); photoacoustic imaging (PAI); magnetic resonance angiography (MRA)

\section{Introduction}

The brain is one of the most sophisticated and complex organs generated by evolution and its impressive anatomical composition and its entangled functionality has been admired for thousands of years. Although early civilizations lacked adequate means to obtain knowledge about the nervous system, the ancient Egyptians in the 17th century Before Common Era (BCE) wrote the earliest recorded reference to the brain in the Edwin Smith papyrus [1]. It was not until the 5th century BCE that the concept of the nervous system appeared [2]. In the 1600s, William Harvey proved the theory of blood circulation in De Motu Cordis [3], although the first descriptions of the pulmonary circulation by Ibn al-Nafis date back to the 16th century BCE [4]. The interest in dynamics stimulated the study of angiology and neuroanatomy and, in 1664, Thomas Willis published Cerebri anatome, a text on the brain that was a groundbreaking work for neuroscience and remained very influential for the next two centuries [5,6].

In 1882, Angelo Mosso invented the first neuroimaging technique, called "human circulated balance" that could non-invasively measure the redistribution of blood during emotional and intellectual activity [7]. Nevertheless, the origin of structural imaging was the X-ray, discovered by Roentgen in 1895 [8]. Shortly after, Haschek and Lindenthal produced radiographs of blood vessels by injecting opaque solution into cadavers; however, it was not until 1927 that Egas Moniz performed the first cerebral angiography in humans [9]. Since then, key events and major technological innovations in physics, mathematics, computing and clinical imaging have promoted the development of at least the following techniques: (1) computed tomography (CT), for which Hounsfield and Cormack were awarded the Nobel Prize in 1979; (2) positron emission tomography (PET) [10]; and (3) magnetic resonance imaging (MRI), for which Lauterbur and Mansfield were awarded the Nobel Prize in 2003 and magnetic resonance angiography (MRA). The abovementioned techniques together with other imaging modalities, including digital subtraction angiography (DSA), photoacoustic imaging (PAI) and trans-cranial doppler (TCD), have contributed to the knowledge of the brain vasculature, promoting and improving our understanding of the complexity of the central nervous system (CNS). 
The strategies that scientists have adopted for studying the brain have varied over the years as new techniques and methods have been developed. Elucidating the composition and functions of the brain is one of the most challenging areas of research. Characterizing the structure of the brain at high resolution is crucial for understanding its functions and dysfunction. Neuroimaging, the process of producing images of the structure or activity of the brain, is becoming an increasingly important tool in both research and clinical care, tremendously helping our understanding of brain morphology and physiology in healthy and disease states.

The aim of this review is to give a short overview of the most important recent scientific advances achieved using imaging techniques, with particular focus on their relevance to the field of brain vascular imaging and including a section on molecular imaging of the blood-brain barrier (BBB). A special focus on animal models is also included, as their use is motivated by a desire to better understand human diseases. Moreover, a summary of available online brain atlases for both human and animal models and the way these approaches contribute to a better understanding of the brain on multiple levels are also highlighted.

\section{Computed Tomography (CT)}

On October 1, 1971, in London, England, CT imaging performed by Godfrey Hounsfield and James Ambrose produced the first scan of a patient with a cerebral cyst. The image proved it was possible to produce non-superimposed images of an object slice [11].

Since that time, CT has been improved by a number of important technological advancements, leading to the current ability to acquire thousands of thin-slice images with voxel isotropy in a few seconds with a reduced radiation dose [12,13]. CT angiography (CTA) has gained the most benefit from such evolution in terms of improved diagnostic performance and broadened clinical indications [14,15]. Color-coded CT angiography, a new method of displaying dynamic cerebral CT angiography, provides important additional information on cerebral hemodynamics, including specifically differentiation between antegrade and retrograde flow [16].

Micro-scale computed tomography (microCT) $[17,18]$ and nano-computed tomography (nanoCT) [19] are high-resolution cross-sectional imaging techniques and are essential tools for phenotyping and for elucidating diseases and their therapies. Compared to other imaging methods, the strengths of microCT and nanoCT lay with their high-resolution scanning efficiency, velocity and relatively low cost. Additionally, it is a structural imaging modality that provides a high-resolution volumetric representation of vascular structures in brains of rodents [20-24] as well as measurements of cerebral blood volume (CBV) [25].

Recent applications of microCT to the mouse brain vasculature include the in situ analysis of adult brains using iodine-based contrast [26], the evaluation of animal models of cerebral cavernous malformations (CCM) [27] and the imaging of brain tumors in live mice [28].

Perfusion CT is a relatively new imaging technique that allows rapid qualitative and quantitative evaluation of cerebral vascular physiology and hemodynamics including measurement of cerebral blood flow (CBF) and CBV. It involves the sequential acquisition of cerebral CT images performed during the intravenous administration of contrast material [29]. It is an alternative imaging modality with several clinical indications including stroke [30], head trauma [31] and brain tumors [32]. Published data have suggested that perfusion CT might be comparable to MRI [33,34]. Moreover, perfusion $\mathrm{CT}$ has been used to evaluate possible clinical benefits of pharmacology therapy in early stroke onset [35], as well as to predict survival in in high-grade gliomas [36]. 


\section{Positron Emission Tomography (PET) and Single Photon Emission Computed Tomography (SPECT)}

The development of CT soon led to other imaging techniques, including PET [37,38], which involves injecting rapidly decaying radioactive substances into the bloodstream. The first simple PET scanner able to detect brain tumors was made in the early 1950s by Bromwell and Sweet and by 1975, more sophisticated types of PET, which could measure blood flow, were developed [39-41].

The first PET image of a rat brain using a clinical PET scanner was performed in 1991 [42] and the initial dedicated small PET scanner was introduced several years later in 1995 [43]. The recent development of a high-resolution small animal PET scanner suitable for imaging the mouse brain will quickly improve the imaging quality of brain analysis [44].

PET functional imaging is most useful in combination with anatomical imaging and hybrid imaging systems such as PET/MRI [45,46] and PET/CT [47,48]. Multimodality imaging PET/CT and PET/MRI provide advantages in the imaging evaluation of patients with a variety of diseases [49]. A PET/CT scanner has the ability to improve image quality and image accuracy of PET images, enhancing lesion identification and localization, which affects clinical decision making and thereby improves patient management [50-52]. PET/MRI combination offers functional structural and metabolic data, which can potentially contribute to more accurate diagnoses and ultimately affect patient survival. The advantages and drawbacks of PET/CT are discussed in [53,54].

Multimodality imaging is nowadays available in the clinical practice and for small animals [55]. Rodent SPECT/CT has been used to assess in vivo CBF and blood-brain barrier (BBB) disruption after focal cerebral ischemia [56] and the recently developed trimodal PET/SPECT/CT scanner for small animals [57] has allowed for new insights into brain function and the visualization of cerebral ischemia in living rats [58].

PET and single photon emission computed tomography (SPECT) $[59,60]$ are molecular imaging modalities which by the use of specific radioactive tracers, allow visualization and measurement of physiological processes in intact living brains [61].

Recently PET has been used to study hypoxia and inflammation in ischemic stroke [62-65], to explore the possible relationship between an acute ischemic stroke and $A \beta$ deposition in patients [66], and to noninvasively image VEGFR expression kinetics to analyze post stroke angiogenesis in rats [67]. Moreover, ${ }^{11} \mathrm{C}$-methionine is the most popular tracer used in PET imaging of brain tumors [68], and can predict prognosis in gliomas [69]. Other recent examples of brain vascular disorders imaged utilizing PET or SPECT include thrombosis [70], Alzheimer's [71] and Moyamoya disease [72].

\section{Magnetic Resonance Imaging (MRI) and Other Similar Techniques}

The basic idea behind the MR phenomenon first appeared in 1946 from discoveries by Bloch and Purcell. It took another 25 years before MRI was applied to medical diagnosis, when the first discoveries concerning the development of the technique to visualize different structures were published [73-75]. A great advantage with MRI is that it uses magnetic forces rather than potentially harmful ionizing radiation. Moreover, image quality has advanced to a remarkable extent with scan times decreasing by factors of 10 to 100 since the early 1980s [76,77].

The main concepts required to understand MRI include the classification of the image contrast following its sensitivity to three different parameters: proton density $(\rho)$, the spin-lattice or longitudinal relaxation times $T_{1}$, and the spin-spin or transverse relaxation times $T_{2}$ or $T_{2}{ }^{*}$. A proton-density-weighted image is a sequence that is mainly sensitive to $\rho$ and $T_{1}$ - or $T_{2}$-weighted images are, respectively, sensitive to $T_{1}$ or $T_{2}$ relaxation times [78]. Additionally, different contrast agents, which enrich MRI, can be used in the so-called Contrast-Enhanced MRI [79]. Several reviews have recently focused on cerebrovascular MRI, compared to other imaging techniques and described the key developments in the last years [12,80-83].

These new advances in neuroimaging methods could also be applied as biomarkers [84]. Biomarkers can be used as a diagnostic tool, a prognostic tool, a predictive tool (for predicting 
response to an intervention), or a substitute for a clinical outcome to measure the response to an intervention (surrogate end point). Some examples of biomarkers based on MR imaging used in acute ischemic stroke are summarized in [85]. Biomarkers based on brain imaging may relate to prognosis in high-grade gliomas [86] and recently, vessel caliber analysis has been proposed as a possible biomarker of tumor response in clinical trials, revised in [87].

The study of hemodynamic alterations in patients with cerebrovascular disease is important to understand the disease, potentially improving diagnostic capabilities and therapeutic planning. There is a demand for noninvasive imaging of cerebrovascular territories; therefore, new emerging techniques for evaluation cerebrovascular hemodynamics and CBF [88], including four-dimensional (4D) flow MRI [89-92]; 2D phase contrast MRI (PC-MRI) [93-95] and magnetic resonance black-blood thrombus imaging technique (MRBTI) [96] are being developed.

\subsection{Diffusion and Perfusion Weighted MRI.}

Diffusion (DWI) and perfusion (PWI) weighted MRI have an increasingly important clinical role (see [97] for a detailed description of the basic principles). The combination of both techniques is especially promising for the early detection and assessment of stroke [98,99]; and for brain tumor characterization [100], as they provide complementary information.

DWI is based on the random movement of water molecules caused by their kinetic energy dissipation, known as Brownian motion, in the presence of magnetic pulses. The apparent diffusion coefficient is a measure that displays the magnitude of diffusion of the water molecules within tissue [101,102]. In the field of brain imaging, DWI has been applied to diagnose and monitor stroke $[103,104]$ and characterize brain tumors [105].

PWI refers to methods that make use of the effect of endogenous or exogenous tracers on the MR images for deriving various hemodynamic parameters offering the potential for measuring brain perfusion in several pathological conditions including stroke [106] and brain tumors $[107,108]$. Perfusion MRI techniques can be used for quantitative assessment of specific pathophysiologic parameters, more accurate grading of intracranial tumors and may predict survival and patient outcome $[109,110]$.

\subsection{Susceptibility-Weighted Imaging (SWI)}

SWI is an MRI technique that enhances image contrast by using the susceptibility differences between tissues and has become a part of routine brain MRI protocols [111]. The clinical success of SWI arises from its superior sensitivity for detecting small quantities of blood product, its ability to differentiate between arterial and venous vessels, and its ability to differentiate between calcification and blood product. Thus, SWI is nowadays utilized to obtain images of diverse brain vascular disorders including: hemorrhages, traumatic brain injury, stroke, tumors and multiple sclerosis [112-114]. The fact that this technique does not provide quantitative measurements, which is an important limitation, is currently overcome by the advancement of new technology such as quantitative susceptibility mapping (QSM) [115] and susceptibility tensor imaging (STI) [116].

\subsection{Quantitative Susceptibility Mapping (QSM)}

QSM [117] is expected to play an increasing role in the clinic as it permits to unambiguously differentiate between calcified and hemorrhagic lesions which permits a differential diagnosis and simultaneously reveals brain anatomy. This technique allows investigating and obtaining valuable information not only on compositional changes in aging brain, but also in numerous neurodegenerative disorders, providing valuable guidance to clinicians during diagnosis.

QSM has recently been applied to monitor CCM disease progression and iron deposition [118,119], intracranial hemorrhages [120], hematoma volume [121] and to differentiate hemorrhages from calcifications [122]. The usefulness of QSM in visualizing the microstructure of the mouse brain at a $10 \mu \mathrm{m}$ resolution, has been shown by the revealing of detailed structures [123]. 


\subsection{Intracranial Vessel Wall Imaging (IVW)}

Recently available IVW methods provide the possibility of directly assessing the vessel wall [124-127], providing a useful diagnostic tool, which may improve patient outcomes by helping treatment choice, in comparison to other invasive and non-invasive methods currently available. IVM is especially challenging due to the small caliber and tortuosity of the intracranial vessels and is an upcoming field of interest to assess intracranial atherosclerotic lesions [128-130], intracranial vasculopathies [131,132], cerebrovascular inflammation [133], CNS vasculitis [134], brain arteriovenous malformations [135], Moyamoya disease [136,137], Cerebral aneurysms [138-140] and intracranial arterial dissection [141].

\subsection{MR Angiography (MRA)}

MRA is a group of techniques based on MRI to image blood vessels [142,143]. MRA techniques can be divided into two categories: contrast-enhanced and non-contrast enhanced MRA. Since its introduction in 1994 by Prince [144], first-pass contrast-enhanced MRA has seen widespread acceptance and details about techniques and contrast agents are reported in [145-149]. A detailed description of non-contrast MRA techniques and the physical mechanisms underlying each method including their clinical applications can be found in [150] and [151]. In the brain, MRA is used to visualize cerebrovascular territories [152,153], and to evaluate stenosis and occlusions [154], aneurysms [155] and other cerebral malformations [156]. A complete description of MRA in brain vascular disorders is reviewed in [157].

\section{Digital Subtraction Angiography (DSA)}

DSA is an imaging method that permits a distinct visualization of the vasculature in a skeletal or dense soft tissue environment. The introduction of the technique in 1980 provided a method for real-time 2D subtraction imaging, spawning a steady progression of related methods, including 3D [158] and 4D DSA [159] (an outline of some historical milestones and future directions are nicely reviewed in $[160,161])$.

An overview of the technical principles of DSA can be found in [162,163]. Briefly, the target tissue is initially exposed to X-ray or MRI, to obtain the first set of images; then a contrast agent is administered into the vasculature and additional X-ray or MRI are obtained. The mask, which is the first set of images, is then subtracted from the latter or contrast enhanced images, allowing the visualization of the vascular structure free of the surrounding tissue.

DSA can be utilized to visualize intracranial vascular structures [164], vascular abnormalities such as arteriovenous malformations [165], aneurysms [166], carotid stenosis [167], as well as grading Moyamoya disease [168] and collateral flow in acute middle cerebral artery occlusion [169].

\section{Trans-Cranial Doppler (TCD)}

TCD ultrasound is a specialized technique introduced in 1982 by Rune Aaslid for detecting blood flow in the basal intracerebral arteries [170]. It is a noninvasive technique that involves the use of a low-frequency $(\leq 2 \mathrm{MHz})$ transducer probe to insonate specific areas of the cranium that are relatively thin. TCD enables users to acquire images of some of the major intracranial vessels through the intact skull and monitor cerebral blood flow (CBF) velocity and vessel pulsatility over extended time periods with a high temporal resolution. [171]. Advanced applications of TCD in neurovascular diseases have been extensively revised in [172-175].

\section{Photoacoustic Imaging (PAI)}

Photoacoustic imaging (PAI) is also called optoacoustic imaging and is an emerging imaging modality that shows great potential for preclinical research and clinical practice [176]. The method is based on the photoacoustic effect; briefly, the tissue of interest is excited by a pulsed laser and part 
of the locally absorbed light produces thermal excitation, leading to an expansion of the tissue and subsequent generation of ultrasonic waves. Ultrasonic transducers detect the emitted ultrasonic waves, which are finally converted into images.

The applications in biomedicine of the photoacoustic effect, first reported by Alexander Graham Bell in 1880, began in the 1970s [177] but progressed slowly until the last decade of the 20th century, when many pioneering works demonstrated the photoacoustic effect in optically scattering media and biological tissue, extensively reviewed in [178-180].

As a hybrid technique, PAI is based on the acoustic detection of optical absorption from either endogenous chromophores or exogenous contrast agents [181], such as chemical dyes [182], nanoparticles $[183,184]$ and reporter genes $[185,186]$. PAI is especially useful in visualizing blood vessels in vivo due to the fact that blood hemoglobin and deoxyhemoglobin, have a substantially higher absorption than surrounding tissues and therefore create sufficient endogenous contrast. Over the past decade, the photoacoustic technique has been evolving rapidly, leading to a variety of exciting discoveries and applications such as photoacoustic tomography (PAT) that is cross-sectional or three-dimensional (3D) PAI [187-189].

PAT allows visualizing and studying a diverse range of structures: from organelles to whole organs [190] and based on the spatial resolution of the method, PAT is classified into optical-resolution photoacoustic microscopy (OR-PAM) [191], acoustic-resolution photoacoustic microscopy (AR-PAM) [192], photoacoustic computed tomography (PACT) [193,194], and photoacoustic endoscopy (PAE) [195].

PAI has been successfully used in the past few years in small animal models to image the brain [196,197] and determine CBF though the intact skull [198]. Recently, a wearable system has been developed that is capable of providing images of cerebral blood vessels noninvasively [199]. Moreover, PAI is a new strategy to visualize and study several brain disorders [200] including stroke [201-203], brain tumors [204-206]; cerebral edema [207], epilepsy [208]; traumatic brain injury [209] and inflammation [210].

PAT imaging in patients with brain pathologies is currently not used in clinical practice and is still under development. The main challenge and limitation in humans is the thickness of the skull, but promising recent advances suggest that this technology could be implemented as a clinical device for noninvasive functional brain imaging [184,211-213].

\section{Molecular Imaging of the Blood-Brain Barrier (BBB)}

Multiple cell types, which coordinately form the neurovascular unit (NVU), include neurons; vascular cells (endothelial cells (EC), smooth muscle cells and pericytes); and glia (astrocytes, microglia and oligodendroglia), which are key factors to maintaining CNS functions. Within the NVU, the EC form the BBB that limits entry of substances into the brain and maintains the ideal environment for the brain to properly function $[214,215]$.

A detailed molecular atlas of the BBB transport systems and cellular functions, based on available data on protein and RNA expression, as well as physiological measurements from different published investigations, is meticulously provided in this recent review [216].

Dysfunction of the BBB has been shown to be a common denominator in many CNS disease pathogeneses observed in stroke, cerebral edema, Parkinson's disease, Alzheimer's disease, seizures, microcephaly and CCMs, among others [214,217,218].

Work in key molecular components of the ECs composing the BBB-including macromolecule transporters such as the glucose transporter GLUT1 [219]; the major facilitator superfamily domain-containing protein 2a (MFSD2a) [220,221]; and tight junction complexes [222], such as Occuldin [223]; and the junctional adhesion molecule C (JAM-C) [224]-and their implication in several brain diseases with BBB dysfunction and altered cerebrovascular integrity have raised the interest in molecular imaging of the BBB.

Dynamic contrast-enhanced MRI (DCE-MRI) is the most widely used imaging method for assessing BBB integrity [225-228]. It has been used to asses abnormal BBB permeability in several 
pathological conditions including: traumatic brain injury [229], vascular cognitive impairment [230], multiple sclerosis [231], Alzheimer's disease [232], brain tumors [233] and stroke [234].

The development of novel state-of-the art neuroimaging and molecular biomarker approaches are key aspects of future investigations addressing whether molecular and imaging biomarkers of BBB dysfunction can serve as reliable prognostic and/or diagnostic tools to predict the development of several CNS disorders [235].

\section{Transgenic Animal Models for Vascular Biology}

Recent advances in imaging techniques $[236,237]$ together with the development of tissue-clearing methods, facilitating volumetric imaging without sectioning [238-240], do now provide the possibility, with adequate resolution, to obtain live imaging data from the vasculature in organs and even whole experimental animals during development and disease conditions.

The development of transgenic animal models with fluorescent markers for specific proteins or specific vascular cell types are necessary to fully benefit from the newly available microscope techniques.

So far, zebrafish has been the most suitable animal model to perform in vivo live imaging experiments of the vascular system. Therefore, several transgenic lines, which express different kinds of fluorescent probes in vascular cell types, are currently available and have extensively contributed to improving our knowledge of key vascular processes such as lumen formation, angiogenic sprouting, remodeling, cell proliferation and circulation of blood cells, reviewed in [241,242].

Although the establishment of fluorescent vascular reporters in mice models to study vascular biology has been slower, it is in fact becoming more relevant. Some transgenic mouse lines are already available and label different cell types including: EC [243-252]; lymphatic endothelial cells (LEC) [253-257], reviewed in [258] and pericytes [259-261]. While the above referenced transgenic lines are useful reporters for the major vascular cell types, other transgenic lines have been developed to visualize various organelles or subcellular structures [262-265].

The effort to develop new tools such as florescent reporter mice is not only performed by single scientific groups but also by joined projects. One example is the Gene Expression Nervous System Atlas (GENSAT) project, which is mapping the expression pattern of genes in the CNS and has created several mouse reporters, expressing enhanced green fluorescent protein (EGFP) and td-Tomato, to investigate the distinct gene expression patterns [266] (www.gensat.com). Moreover, other interesting fluorescent reporter mice are also available in the Jackson Laboratory (www.jax.org).

\section{Brain Atlases}

Another useful tool generated using some of the imaging methods mentioned in this review are brain atlases [267]. Brain atlases are applicable in in all areas of neuroscience including research, education and clinical applications. An enormous amount of data is produced every day in laboratories worldwide regarding brain mapping, and there are many initiatives to make these data available through public databases. At present, brain atlases are printed, electronic, web-based and some are even available on mobile platforms [268].

The recent technical advances in areas such as sample preparation, optical techniques, quantitative 2D and 3D imaging analysis and high-performance computing, have relevantly contributed to the development of new brain mapping approaches (reviewed in [269]). The latest news about the worldwide brain research initiatives can be found in [270].

Following the publication of the mouse [271], adult [272] and prenatal [273] human brain gene expression atlases in recent years, a high-resolution transcriptional atlas of pre- and post-natal brain development for the rhesus monkey has now become available [274].

Table 1 gives examples of some of the most relevant web-based brain atlases in human, rodents and other species [271,272,274-293]. 
Table 1. Examples of available online brain atlases.

\begin{tabular}{|c|c|c|c|c|}
\hline Specie & Atlas Name & Comments & Link & Selected References \\
\hline \multirow{11}{*}{ Human } & $\begin{array}{l}\text { The Human Brain Atlas at } \\
\text { Michigan State University }\end{array}$ & $\begin{array}{l}\text { MRI from one specimen + myelin and cell } \\
\text { bodies staining }\end{array}$ & https://msu.edu/ brains/brains/human/index.html & $\begin{array}{l}\text { Tool developed by } \\
\text { Sudheimer, K.D.; Winn, B.M.; } \\
\text { Kerndt, G.M.; Shoaps, J.M.; } \\
\text { Davis, K.K.; Fobbs Jr., A.J.; } \\
\text { Johnson; J.I. }\end{array}$ \\
\hline & Allen Brain Atlas & MRI, in situ hybridization, microarray & http://human.brain-map.org/ & {$[272,275,276]$} \\
\hline & Scalable Brain Atlas & Brain atlas templates for different species & https://scalablebrainatlas.incf.org/main/index.php & [277] \\
\hline & Atlas of the Human Brain & Macroscopic and microscopic levels & http://www.thehumanbrain.info/ & [293] \\
\hline & Human Connectome Project & $\begin{array}{l}\text { MRI-based imaging modalities to measure } \\
\text { brain architecture, function and connectivity }\end{array}$ & http://www.humanconnectomeproject.org/ & [278-281] \\
\hline & BigBrain & Cell bodies' staining & https://bigbrain.loris.ca/main.php & [282] \\
\hline & Jubrain & $\begin{array}{l}\text { Probabilistic maps based on post } \\
\text { mortem brains }\end{array}$ & https://www.jubrain.fz-juelich.de/apps/cytoviewer/cytoviewer-main.php & [283] \\
\hline & The Whole Brain Atlas & $\begin{array}{l}\text { Contains atlas from different } \\
\text { cerebrovascular diseases }\end{array}$ & http://www.med.harvard.edu/aanlib/home.html & [284] \\
\hline & Human Brainnetome Atlas & Structural and connectivity features & http://atlas.brainnetome.org/ & [285] \\
\hline & $\begin{array}{l}\text { Brain Development Atlases } \\
\text { (Imperial College London) }\end{array}$ & $\begin{array}{l}\text { Different atlas datasets are available } \\
\text { (adult, pediatric and neonatal) }\end{array}$ & http://brain-development.org/brain-atlases/ & [286-288] \\
\hline & FSL Atlas & $\begin{array}{l}\text { Library of analysis tools for FMRI, MRI and } \\
\text { DTI brain imaging data }\end{array}$ & http:/ /fsl.fmrib.ox.ac.uk/fsl/fslwiki/ & [289] \\
\hline \multirow{3}{*}{ Rodents } & Allen Brain Atlas & $\begin{array}{l}\text { Includes developing brain, spinal cord and } \\
\text { connectivity brain atlas }\end{array}$ & http://mouse.brain-map.org/ & {$[271,276]$} \\
\hline & Mouse Atlas Project & Contains also a neonatal brain atlas & http://map.loni.usc.edu/ & [290] \\
\hline & The Mouse Brain Library & Includes developing mouse brain atlas & http://www.mbl.org/ & $\begin{array}{l}\text { Tool developed by } \\
\text { Williams, R.W. and colleagues }\end{array}$ \\
\hline \multirow{3}{*}{ Others } & Zebrafish Brain Atlas & $\begin{array}{l}\text { Includes information about the neuroanatomy } \\
\text { of the developing zebrafish brain }\end{array}$ & http://zebrafishbrain.org/ & [291] \\
\hline & $\begin{array}{l}\text { Blueprint Atlas } \\
\text { (Rhesus macaque) }\end{array}$ & Gene expression data, neuroanatomical data & http://www.blueprintnhpatlas.org/ & {$[274]$} \\
\hline & $\begin{array}{l}\text { Virtual Fly Brain } \\
\text { (Drosophila melanogaster) }\end{array}$ & Neural anatomy and imaging data & http://www.virtualflybrain.org/ & [292] \\
\hline
\end{tabular}




\section{Conclusions}

Imaging is becoming an increasingly important tool in research and clinical care. A range of imaging techniques now provides unprecedented capacity to visualize the structure of the brain, including the vasculature, from the level of individual molecules and encompassing the whole brain. Most imaging methods are noninvasive and allow monitoring dynamic processes over time. Imaging enables researchers to identify brain vascular abnormalities, understand disease pathways, evaluate blood-brain barrier (BBB) integrity, recognize and diagnose pathologies and determine efficacy of different therapies and treatments. Each technique has strengths and weaknesses relating to cost, availability, temporal and spatial resolution and risk factors, thus improving our knowledge and ensuring the innovation of such tools will be beneficial in the near future.

The imaging techniques described in this review, alone and in combination, contribute to transforming and improving our understanding of how the brain functions in health and disease.

Acknowledgments: I acknowledge Christer Betsholtz for scientific support and Jennifer Hofmann for textual suggestions and corrections. Bàrbara Laviña was supported by the Spanish Ministry of Education through a Fundación Española para la ciencia y la tecnología (FECYT) grant, via the postdoctoral mobility contract EDU $/ 2934 / 2009$.

Conflicts of Interest: The author declares no conflict of interest.

\section{Abbreviations}

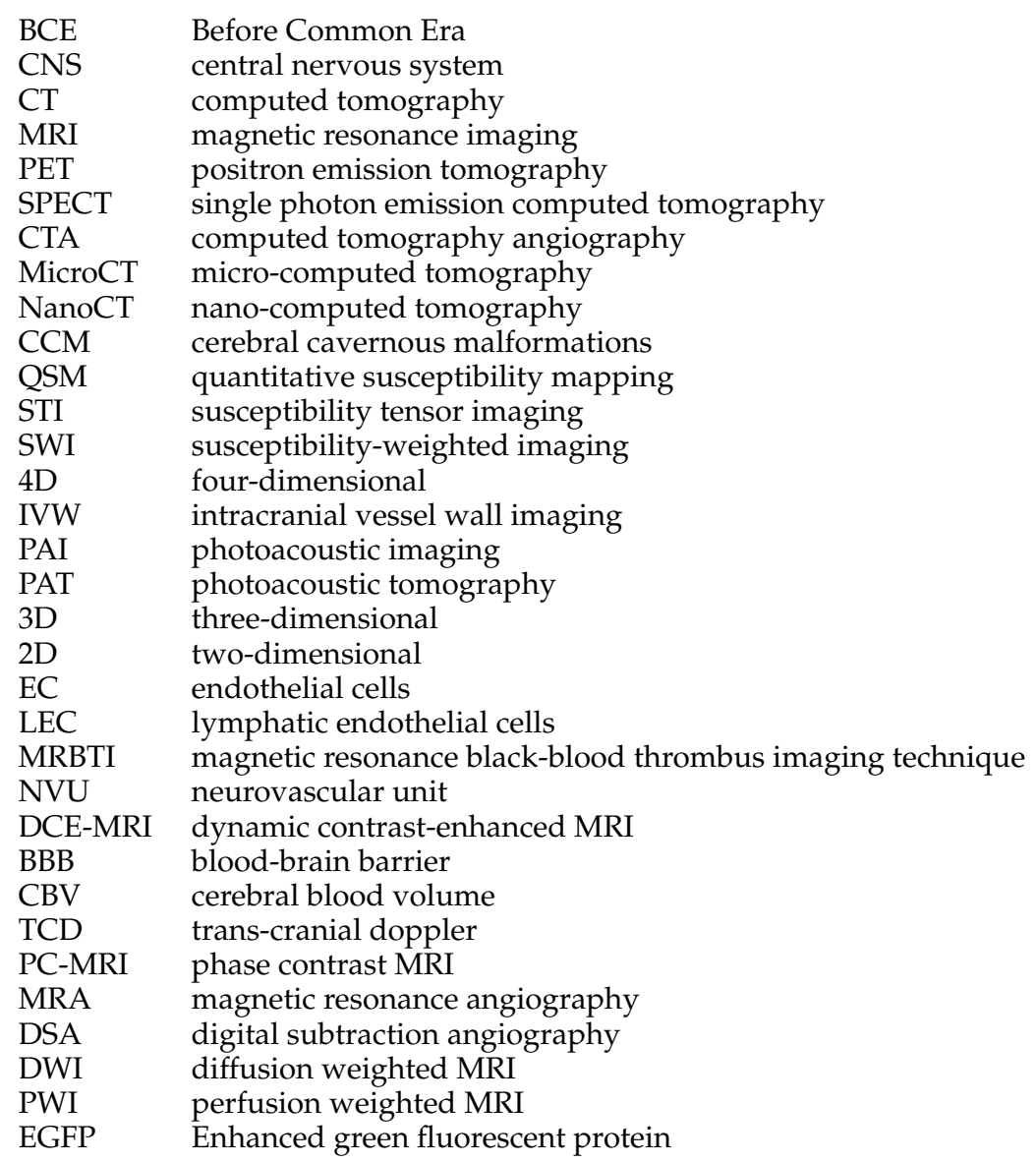

\section{References}

1. Breasted, J.H. (Ed.) The Edwin Smith Surgical Papyrus. Published in Faesimile and Hieroglyphie Transliteration, with Translation and Commentary; The Univesity of Chicago Press: Chicago, IL, USA, 1930.

2. Wickens, A.P. A History of the Brain: From Stone Age surgery to Modern Neuroscience; Psychology Press: London, UK; New York, NY, USA, 2015; p. 27. 
3. Aird, W.C. Discovery of the cardiovascular system: From Galen to William Harvey. J. Thromb. Haemost. 2011, 9, 118-129. [CrossRef] [PubMed]

4. Numan, M.T. Ibn Al Nafis: His seminal contributions to cardiology. Pediatr. Cardiol. 2014, 35, $1088-1090$. [CrossRef] [PubMed]

5. O'Connor, J.P.B. Thomas Willis and the background to Cerebri Anatome. J. R. Soc. Med. 2003, 96, 139-143. [CrossRef] [PubMed]

6. Eadie, M.J. A pathology of the animal spirits-The clinical neurology of Thomas Willis (1621-1675) part I-Background, and disorders of intrinsically normal animal spirits. J. Clin. Neurosci. 2003, 10, 14-29. [CrossRef]

7. Sandrone, S.; Bacigaluppi, M.; Galloni, M.R.; Cappa, S.F.; Moro, A.; Catani, M.; Filippi, M.; Monti, M.M.; Perani, D.; Martino, G. Weighing brain activity with the balance: Angelo Mosso's original manuscripts come to light. Brain 2014, 137. [CrossRef] [PubMed]

8. Weber, A.L. History of head and neck radiology: Past, present, and future. Radiology 2001, 218, 15-24. [CrossRef] [PubMed]

9. Antunes, J.L. Egas Moniz and cerebral angiography. J. Neurosurg. 1974, 40, 427-432. [CrossRef] [PubMed]

10. Zimmer, L.; Luxen, A. PET radiotracers for molecular imaging in the brain: Past, present and future. Neuroimage 2012, 61, 363-370. [CrossRef] [PubMed]

11. Petrik, V.; Apok, V.; Britton, J.A.; Bell, B.A.; Papadopoulos, M.C. Godfrey Hounsfield and the dawn of computed tomography. Neurosurgery 2006, 58, 780-787. [CrossRef] [PubMed]

12. Runge, V.M.; Aoki, S.; Bradley, W.G.; Chang, K.-H.; Essig, M.; Ma, L.; Ross, J.S.; Valavanis, A. Magnetic Resonance Imaging and Computed Tomography of the Brain-50 Years of Innovation, With a Focus on the Future. Investig. Radiol. 2015, 50, 551-556. [CrossRef] [PubMed]

13. Lell, M.M.; Wildberger, J.E.; Alkadhi, H.; Damilakis, J.; Kachelriess, M. Evolution in Computed Tomography: The Battle for Speed and Dose. Investig. Radiol. 2015, 50, 629-644. [CrossRef] [PubMed]

14. Kamalian, S.; Lev, M.H.; Gupta, R. Computed tomography imaging and angiography-Principles. Handb. Clin. Neurol. 2016, 135, 3-20. [PubMed]

15. Fleischmann, D.; Chin, A.S.; Molvin, L.; Wang, J.; Hallett, R. Computed Tomography Angiography: A Review and Technical Update. Radiol. Clin. N. Am. 2016, 54, 1-12. [CrossRef] [PubMed]

16. Thierfelder, K.M.; Havla, L.; Beyer, S.E.; Ertl-Wagner, B.; Meinel, F.G.; von Baumgarten, L.; Janssen, H.; Ditt, H.; Reiser, M.F.; Sommer, W.H. Color-coded cerebral computed tomographic angiography: Implementation of a convolution-based algorithm and first clinical evaluation in patients with acute ischemic stroke. Investig. Radiol. 2015, 50, 361-365. [CrossRef] [PubMed]

17. Schambach, S.J.; Bag, S.; Schilling, L.; Groden, C.; Brockmann, M.A. Application of micro-CT in small animal imaging. Methods 2010, 50, 2-13. [CrossRef] [PubMed]

18. Clark, D.P.; Badea, C.T. Micro-CT of rodents: State-of-the-art and future perspectives. Phys. Med. 2014, 30, 619-634. [CrossRef] [PubMed]

19. Kampschulte, M.; Langheinirch, A.C.; Sender, J.; Litzlbauer, H.D.; Althöhn, U.; Schwab, J.D.; Alejandre-Lafont, E.; Martels, G.; Krombach, G.A. Nano-Computed Tomography: Technique and Applications. In RöFo-Fortschritte auf dem Gebiet der Röntgenstrahlen und der bildgebenden Verfahren; Georg Thieme Verlag KG: Stuttgart, Germany, 2016; Volume 188, pp. 146-154.

20. Dorr, A.; Sled, J.G.; Kabani, N. Three-dimensional cerebral vasculature of the CBA mouse brain: A magnetic resonance imaging and micro computed tomography study. Neuroimage 2007, 35, 1409-1423. [CrossRef] [PubMed]

21. Schambach, S.J.; Bag, S.; Groden, C.; Schilling, L.; Brockmann, M.A. Vascular imaging in small rodents using micro-CT. Methods 2010, 50, 26-35. [CrossRef] [PubMed]

22. Starosolski, Z.; Villamizar, C.A.; Rendon, D.; Paldino, M.J.; Milewicz, D.M.; Ghaghada, K.B.; Annapragada, A.V. Ultra High-Resolution In vivo Computed Tomography Imaging of Mouse Cerebrovasculature Using a Long Circulating Blood Pool Contrast Agent. Sci. Rep. 2015, 5, 10178. [CrossRef] [PubMed]

23. Ghanavati, S.; Yu, L.X.; Lerch, J.P.; Sled, J.G. A perfusion procedure for imaging of the mouse cerebral vasculature by X-ray micro-CT. J. Neurosci. Methods 2014, 221, 70-77. [CrossRef] [PubMed]

24. Mancini, M.; Greco, A.; Tedeschi, E.; Palma, G.; Ragucci, M.; Bruzzone, M.G.; Coda, A.R.D.; Torino, E.; Scotti, A.; Zucca, I.; et al. Head and Neck Veins of the Mouse. A Magnetic Resonance, Micro Computed Tomography and High Frequency Color Doppler Ultrasound Study. PLoS ONE 2015, 10, e0129912. 
25. Chugh, B.P.; Lerch, J.P.; Yu, L.X.; Pienkowski, M.; Harrison, R.V.; Henkelman, R.M.; Sled, J.G. Measurement of cerebral blood volume in mouse brain regions using micro-computed tomography. Neuroimage 2009, 47, 1312-1318. [CrossRef] [PubMed]

26. Anderson, R.; Maga, A.M. A Novel Procedure for Rapid Imaging of Adult Mouse Brains with MicroCT Using Iodine-Based Contrast. PLoS ONE 2015, 10, e0142974. [CrossRef] [PubMed]

27. Girard, R.; Zeineddine, H.A.; Orsbon, C.; Tan, H.; Moore, T.; Hobson, N.; Shenkar, R.; Lightle, R.; Shi, C.; Fam, M.D.; et al. Micro-computed tomography in murine models of cerebral cavernous malformations as a paradigm for brain disease. J. Neurosci. Methods 2016, 271, 14-24. [CrossRef] [PubMed]

28. Kirschner, S.; Felix, M.C.; Hartmann, L.; Bierbaum, M.; Maros, M.E.; Kerl, H.U.; Wenz, F.; Glatting, G.; Kramer, M.; Giordano, F.A.; et al. In vivo micro-CT imaging of untreated and irradiated orthotopic glioblastoma xenografts in mice: Capabilities, limitations and a comparison with bioluminescence imaging. J. Neurooncol. 2015, 122, 245-254. [CrossRef] [PubMed]

29. Wintermark, M.; Sincic, R.; Sridhar, D.; Chien, J.D. Cerebral perfusion CT: Technique and clinical applications. J. Neuroradiol. 2008, 35, 253-260. [CrossRef] [PubMed]

30. Lin, L.; Bivard, A.; Krishnamurthy, V.; Levi, C.R.; Parsons, M.W. Whole-Brain CT Perfusion to Quantify Acute Ischemic Penumbra and Core. Radiology 2016, 279, 876-887. [CrossRef] [PubMed]

31. Wintermark, M.; Chioléro, R.; van Melle, G.; Revelly, J.P.; Porchet, F.; Regli, L.; Meuli, R.; Schnyder, P.; Maeder, P. Relationship between brain perfusion computed tomography variables and cerebral perfusion pressure in severe head trauma patients. Crit. Care Med. 2004, 32, 1579-1587. [CrossRef] [PubMed]

32. Jain, R. Perfusion CT imaging of brain tumors: An overview. Am. J. Neuroradiol. 2011, 32, $1570-1577$. [CrossRef] [PubMed]

33. Wintermark, M.; Reichhart, M.; Cuisenaire, O.; Maeder, P.; Thiran, J.-P.; Schnyder, P.; Bogousslavsky, J.; Meuli, R. Comparison of admission perfusion computed tomography and qualitative diffusion- and perfusion-weighted magnetic resonance imaging in acute stroke patients. Stroke 2002, 33, 2025-2031. [CrossRef] [PubMed]

34. Wintermark, M.; Meuli, R.; Browaeys, P.; Reichhart, M.; Bogousslavsky, J.; Schnyder, P.; Michel, P. Comparison of CT perfusion and angiography and MRI in selecting stroke patients for acute treatment. Neurology 2007, 68, 694-697. [CrossRef] [PubMed]

35. Hacke, W.; Furlan, A.J.; Al-Rawi, Y.; Davalos, A.; Fiebach, J.B.; Gruber, F.; Kaste, M.; Lipka, L.J.; Pedraza, S.; Ringleb, P.A.; et al. Intravenous desmoteplase in patients with acute ischaemic stroke selected by MRI perfusion-diffusion weighted imaging or perfusion CT (DIAS-2): A prospective, randomised, double-blind, placebo-controlled study. Lancet Neurol. 2009, 8, 141-150. [CrossRef]

36. Yeung, T.P.C.; Wang, Y.; He, W.; Urbini, B.; Gafà, R.; Ulazzi, L.; Yartsev, S.; Bauman, G.; Lee, T.Y.; Fainardi, E.; et al. Survival prediction in high-grade gliomas using CT perfusion imaging. J. Neurooncol. 2015, 123, 93-102. [CrossRef] [PubMed]

37. Phelps, M.E. PET: The merging of biology and imaging into molecular imaging. J. Nucl. Med. 2000, 41, 661-681. [PubMed]

38. Lameka, K.; Farwell, M.D.; Ichise, M. Positron Emission Tomography. Handb. Clin. Neurol. 2016, 135, 209-227.

39. Nutt, R. 1999 ICP Distinguished Scientist Award. The history of positron emission tomography. Mol. Imaging Biol. 2002, 4, 11-26. [PubMed]

40. Otte, A.; Halsband, U. Brain imaging tools in neurosciences. J. Physiol. 2006, 99, 281-292. [CrossRef] [PubMed]

41. Wagner, H.N., Jr. A brief history of positron emission tomography (PET). Semin. Nucl. Med. 1998, 28, $213-220$. [CrossRef]

42. Ingvar, M.; Eriksson, L.; Rogers, G.A.; Stone-Elander, S.; Widén, L. Rapid feasibility studies of tracers for positron emission tomography: High-resolution PET in small animals with kinetic analysis. J. Cereb. Blood Flow Metab. 1991, 11, 926-931. [CrossRef]

43. Bloomfield, P.M.; Rajeswaran, S.; Spinks, T.J.; Hume, S.P.; Myers, R.; Ashworth, S.; Clifford, K.M.; Jones, W.F.; Byars, L.G.; Young, J.; et al. The design and physical characteristics of a small animal positron emission tomograph. Phys. Med. Biol. 1995, 40, 1105-1126. [CrossRef] [PubMed] 
44. Yang, Y.; Bec, J.; Zhou, J.; Zhang, M.; Judenhofer, M.S.; Bai, X.; Di, K.; Wu, Y.; Rodriguez, M.; Dokhale, P.; et al. A Prototype High-Resolution Small-Animal PET Scanner Dedicated to Mouse Brain Imaging. J. Nucl. Med. 2016, 57, 1130-1135. [CrossRef] [PubMed]

45. Herzog, H.; Lerche, C. Advances in Clinical PET/MRI Instrumentation. PET Clin. 2016, 11, 95-103. [CrossRef] [PubMed]

46. Cabello, J.; Ziegler, S.I. Advances in PET/MR instrumentation and image reconstruction. Br. J. Radiol. 2016, 89. [CrossRef] [PubMed]

47. Salmon, E.; Ir, C.B.; Hustinx, R. Pitfalls and Limitations of PET/CT in Brain Imaging. Semin. Nucl. Med. 2015, 45, 541-551. [CrossRef] [PubMed]

48. Townsend, DW. Positron emission tomography/computed tomography. Semin. Nucl. Med. 2008, 38, 152-166. [CrossRef] [PubMed]

49. De Galiza Barbosa, F.; Delso, G.; Voert Ter, E.E.G.W.; Huellner, M.W.; Herrmann, K.; Veit-Haibach, P. Multi-technique hybrid imaging in PET/CT and PET/MR: What does the future hold? Clin. Radiol. 2016, 71, 660-672. [CrossRef] [PubMed]

50. Schöder, H.; Erdi, Y.E.; Larson, S.M.; Yeung, H.W.D. PET/CT: A new imaging technology in nuclear medicine. Eur. J. Nucl. Med. Mol. Imaging 2003, 30, 1419-1437. [CrossRef] [PubMed]

51. Ell, P.J. The contribution of PET/CT to improved patient management. Br. J. Radiol. 2006, 79, 32-36. [CrossRef] [PubMed]

52. Alessio, A.M.; Kinahan, P.E.; Cheng, P.M.; Vesselle, H.; Karp, J.S. PET/CT scanner instrumentation, challenges, and solutions. Radiol. Clin. N. Am. 2004, 42, 1017-1032. [CrossRef] [PubMed]

53. Jadvar, H.; Colletti, P.M. Competitive advantage of PET/MRI. Eur. J. Radiol. 2014, 83, 84-94. [CrossRef] [PubMed]

54. Gaertner, F.C.; Fürst, S.; Schwaiger, M. PET/MR: A paradigm shift. Cancer Imaging 2013, 13, 36-52. [CrossRef]

55. Tsoumpas, C.; Visvikis, D.; Loudos, G. Innovations in Small-Animal PET/MR Imaging Instrumentation. PET Clin. 2016, 11, 105-118. [CrossRef] [PubMed]

56. Garrigue, P.; Giacomino, L.; Bucci, C.; Muzio, V.; Filannino, M.A.; Sabatier, F.; Dignat-George, F.; Pisano, P.; Guillet, B. Single photon emission computed tomography imaging of cerebral blood flow, blood-brain barrier disruption, and apoptosis time course after focal cerebral ischemia in rats. Int. J. Stroke 2016, 11, 117-126. [CrossRef] [PubMed]

57. Sánchez, F.; Orero, A.; Soriano, A.; Correcher, C.; Conde, P.; González, A.; Hernández, L.; Moliner, L.; Rodríguez-Alvarez, M.J.; Vidal, L.F.; et al. ALBIRA: A small animal PET/SPECT/CT imaging system. Med. Phys. 2013, 40, 051906. [CrossRef] [PubMed]

58. Balsara, R.D.; Chapman, S.E.; Sander, I.M.; Donahue, D.L.; Liepert, L.; Castellino, F.J.; Leevy, W.M. Non-invasive imaging and analysis of cerebral ischemia in living rats using positron emission tomography with 18F-FDG. J. Vis. Exp. 2014. [CrossRef] [PubMed]

59. Goffin, K.; van Laere, K. Single-photon emission tomography. Handb. Clin. Neurol. 2016, 135, $241-250$. [PubMed]

60. Szigeti, K.; Horváth, I.; Veres, D.S.; Martinecz, B.; Lénárt, N.; Kovács, N.; Bakcsa, E.; Márta, A.; Semjéni, M.; Máthé, D.; et al. A novel SPECT-based approach reveals early mechanisms of central and peripheral inflammation after cerebral ischemia. J. Cereb. Blood Flow Metab. 2015, 35, 1921-1929. [CrossRef] [PubMed]

61. Lu, F.-M.; Yuan, Z. PET/SPECT molecular imaging in clinical neuroscience: Recent advances in the investigation of CNS diseases. Quant. Imaging Med. Surg. 2015, 5, 433-447. [PubMed]

62. Baskin, A.; Buchegger, F.; Seimbille, Y.; Ratib, O.; Garibotto, V. PET Molecular Imaging of Hypoxia in Ischemic Stroke: An Update. Curr. Vasc. Pharmacol. 2015, 13, 209-217. [CrossRef] [PubMed]

63. Kim, S.; Lee, S.; Kim, J.B.; Na, J.O.; Choi, C.U.; Lim, H.-E.; Rha, S.W.; Park, C.G.; Oh, D.J.; Yoo, H.; et al. Concurrent Carotid Inflammation in Acute Coronary Syndrome as Assessed by (18)F-FDG PET/CT: A Possible Mechanistic Link for Ischemic Stroke. J. Stroke Cerebrovasc. Dis. 2015, 24, 2547-2554. [CrossRef] [PubMed]

64. Heiss, W.-D. PET imaging in ischemic cerebrovascular disease: Current status and future directions. Neurosci. Bull. 2014, 30, 713-732. [CrossRef] [PubMed] 
65. Moraga, A.; Gómez-Vallejo, V.; Cuartero, M.I.; Szczupak, B.; San Sebastián, E.; Markuerkiaga, I.; Pradillo, J.M.; Higuchi, M.; Llop, J.; Moro, M.Á.; et al. Imaging the role of toll-like receptor 4 on cell proliferation and inflammation after cerebral ischemia by positron emission tomography. J. Cereb. Blood Flow Metab. 2016, 36, 702-708. [CrossRef]

66. Sahathevan, R.; Linden, T.; Villemagne, V.L.; Churilov, L.; Ly, J.V.; Rowe, C.; Donnan, G.; Brodtmann, A. Positron Emission Tomographic Imaging in Stroke: Cross-Sectional and Follow-Up Assessment of Amyloid in Ischemic Stroke. Stroke 2016, 47, 113-119. [CrossRef] [PubMed]

67. Cai, W.; Guzman, R.; Hsu, A.R.; Wang, H.; Chen, K.; Sun, G.; Gera, A.; Choi, R.; Bliss, T.; He, L.; et al. Positron emission tomography imaging of poststroke angiogenesis. Stroke 2009, 40, 270-277. [CrossRef] [PubMed]

68. Glaudemans, A.W.; Enting, R.H.; Heesters, M.A.; Dierckx, R.A.; van Rheenen, R.W.; Walenkamp, A.M.; Slart, R.H. Value of 11C-methionine PET in imaging brain tumours and metastases. Eur. J. Nucl. Med. Mol. Imaging 2013, 40, 615-635. [CrossRef] [PubMed]

69. Singhal, T.; Narayanan, T.K.; Jacobs, M.P.; Bal, C.; Mantil, J.C. 11C-methionine PET for grading and prognostication in gliomas: A comparison study with 18F-FDG PET and contrast enhancement on MRI. J. Nucl. Med. 2012, 53, 1709-1715. [CrossRef] [PubMed]

70. Ay, I.; Blasi, F.; Rietz, T.A.; Rotile, N.J.; Kura, S.; Brownell, A.L.; Day, H.; Oliveira, B.L.; Looby, R.J.; Caravan, P. In vivo molecular imaging of thrombosis and thrombolysis using a fibrin-binding positron emission tomographic probe. Circ. Cardiovasc. Imaging 2014, 7, 697-705. [CrossRef] [PubMed]

71. Montagne, A.; Nation, D.A.; Pa, J.; Sweeney, M.D.; Toga, A.W.; Zlokovic, B.V. Brain imaging of neurovascular dysfunction in Alzheimer's disease. Acta Neuropathol. 2016, 131, 687-707. [CrossRef] [PubMed]

72. Han, J.-H.; Park, Y.S.; Lee, W.H.; Koong, S.-S.; Min, K.-S.; Lee, M.-S.; Kim, Y.G.; Kim, D.H.; Yi, K.S.; Cha, S.H. Cerebral-perfusion-based single-photon emission computed tomography (SPECT) staging using NeuroGam ${ }^{\circledR}$ in patients with moyamoya disease. Child's Nerv. Syst. 2016, 32, 1471-1477. [CrossRef] [PubMed]

73. Lauterbur, P.C. Image formation by induced local interactions: Examples employing nuclear magnetic resonance. Nature 1973. [CrossRef]

74. Lauterbur, P.C. Magnetic resonance zeugmatography. Pure Appl. Chem. 1974, 40, 149-157. [CrossRef]

75. Mansfield, P.; Maudsley, A.A. Medical imaging by NMR. Br. J. Radiol. 1977, 50, 188-194. [CrossRef] [PubMed]

76. Hollingsworth, K.G. Reducing acquisition time in clinical MRI by data undersampling and compressed sensing reconstruction. Phys. Med. Biol. 2015, 60, R297-R322. [CrossRef] [PubMed]

77. Feinberg, D.A.; Setsompop, K. Ultra-fast MRI of the human brain with simultaneous multi-slice imaging. J. Magn. Reson. 2013, 229, 90-100. [CrossRef] [PubMed]

78. Pooley, R.A. AAPM/RSNA physics tutorial for residents: Fundamental physics of MR imaging. Radiographics 2005, 25, 1087-1099. [CrossRef] [PubMed]

79. Lohrke, J.; Frenzel, T.; Endrikat, J.; Alves, F.C.; Grist, T.M.; Law, M.; Lee, J.M.; Leiner, T.; Li, K.C.; Nikolaou, K.; et al. 25 Years of Contrast-Enhanced MRI: Developments, Current Challenges and Future Perspectives. Adv. Ther. 2016, 33, 1-28. [CrossRef] [PubMed]

80. MacDonald, M.E.; Frayne, R. Cerebrovascular MRI: A review of state-of-the-art approaches, methods and techniques. NMR Biomed. 2015, 28,767-791. [CrossRef] [PubMed]

81. Donahue, M.J.; Strother, M.K.; Hendrikse, J. Novel MRI approaches for assessing cerebral hemodynamics in ischemic cerebrovascular disease. Stroke 2012, 43, 903-915. [CrossRef] [PubMed]

82. Harteveld, A.A.; van der Kolk, A.G.; Zwanenburg, J.J.M.; Luijten, P.R.; Hendrikse, J. 7-T MRI in Cerebrovascular Diseases: Challenges to Overcome and Initial Results. Top. Magn. Reson. Imaging. 2016, 25, 89-100. [PubMed]

83. Macintosh, B.J.; Graham, S.J. Magnetic resonance imaging to visualize stroke and characterize stroke recovery: A review. Front. Neurol. 2013, 4. [CrossRef] [PubMed]

84. Biomarkers Definitions Working Group. Biomarkers and surrogate endpoints: Preferred definitions and conceptual framework. Clin. Pharmacol. Ther. 2001, 69, 89-95.

85. Kidwell, C.S. MRI biomarkers in acute ischemic stroke: A conceptual framework and historical analysis. Stroke 2013, 44, 570-578. [CrossRef] [PubMed]

86. O'Connor, J.P.B.; Jayson, G.C. Do imaging biomarkers relate to outcome in patients treated with VEGF inhibitors? Clin. Cancer Res. 2012, 18, 6588-6598. [CrossRef] [PubMed] 
87. Emblem, K.E.; Farrar, C.T.; Gerstner, E.R.; Batchelor, T.T.; Borra, R.J.H.; Rosen, B.R.; Sorensen, A.G.; Jain, R.K. Vessel caliber-A potential MRI biomarker of tumour response in clinical trials. Nat. Rev. Clin. Oncol. 2014, 11, 566-584. [CrossRef] [PubMed]

88. Fantini, S.; Sassaroli, A.; Tgavalekos, K.T.; Kornbluth, J. Cerebral blood flow and autoregulation: Current measurement techniques and prospects for noninvasive optical methods. Neurophotonics 2016, 3, 031411. [CrossRef] [PubMed]

89. Chang, W.; Huang, M.; Chien, A. Emerging techniques for evaluation of the hemodynamics of intracranial vascular pathology. Neuroradiol. J. 2015, 28, 19-27. [CrossRef] [PubMed]

90. Markl, M.; Schnell, S.; Wu, C.; Bollache, E.; Jarvis, K.; Barker, A.J.; Robinson, J.D.; Rigsby, C.K. Advanced flow MRI: Emerging techniques and applications. Clin. Radiol. 2016, 71, 779-795. [CrossRef] [PubMed]

91. Schnell, S.; Wu, C.; Ansari, S.A. Four-dimensional MRI flow examinations in cerebral and extracerebral vessels - ready for clinical routine? Curr. Opin. Neurol. 2016, 29, 419-428. [CrossRef] [PubMed]

92. Turski, P.; Scarano, A.; Hartman, E.; Clark, Z.; Schubert, T.; Rivera, L.; Wu, Y.; Wieben, O.; Johnson, K. Neurovascular 4DFlow MRI (Phase Contrast MRA): Emerging clinical applications. Neurovasc. Imaging 2016, 2. [CrossRef]

93. Wåhlin, A.; Ambarki, K.; Hauksson, J.; Birgander, R.; Malm, J.; Eklund, A. Phase contrast MRI quantification of pulsatile volumes of brain arteries, veins, and cerebrospinal fluids compartments: Repeatability and physiological interactions. J. Magn. Reson. Imaging 2012, 35, 1055-1062. [CrossRef] [PubMed]

94. Neff, K.W.; Horn, P.; Schmiedek, P.; Düber, C.; Dinter, D.J. 2D Cine Phase-Contrast MRI for Volume Flow Evaluation of the Brain-Supplying Circulation in Moyamoya Disease. Am. J. Roentgenol. 2006, 187, W107-W115. [CrossRef] [PubMed]

95. Enzmann, D.R.; Ross, M.R.; Marks, M.P.; Pelc, N.J. Blood flow in major cerebral arteries measured by phase-contrast cine MR. Am. J. Neuroradiol. 1994, 15, 123-129. [PubMed]

96. Yang, Q.; Duan, J.; Fan, Z.; Qu, X.; Xie, Y.; Nguyen, C.; Du, X.; Bi, X.; Li, K.; Ji, X.; et al. Early Detection and Quantification of Cerebral Venous Thrombosis by Magnetic Resonance Black-Blood Thrombus Imaging. Stroke 2016, 47, 404-409. [CrossRef] [PubMed]

97. Luypaert, R.; Boujraf, S.; Sourbron, S.; Osteaux, M. Diffusion and perfusion MRI: Basic physics. Eur. J. Radiol. 2001, 38, 19-27. [CrossRef]

98. Harris, A.D.; Coutts, S.B.; Frayne, R. Diffusion and perfusion MR imaging of acute ischemic stroke. Magn. Reson. Imaging Clin. N. Am. 2009, 17, 291-313. [CrossRef] [PubMed]

99. Kawada, T. Re: Diagnostic performance of PWI/DWI MRI parameters in discriminating hyper-acute versus acute ischaemic stroke: Finding the best thresholds. Clin. Radiol. 2012, 67, 1218. [CrossRef] [PubMed]

100. Svolos, P.; Kousi, E.; Kapsalaki, E.; Theodorou, K.; Fezoulidis, I.; Kappas, C.; Tsougos, I. The role of diffusion and perfusion weighted imaging in the differential diagnosis of cerebral tumors: A review and future perspectives. Cancer Imaging 2014, 14. [CrossRef]

101. Bammer, R. Basic principles of diffusion-weighted imaging. Eur. J. Radiol. 2003, 45, 169-184. [CrossRef]

102. Hagmann, P.; Jonasson, L.; Maeder, P.; Thiran, J.-P.; Wedeen, V.J.; Meuli, R. Understanding diffusion MR imaging techniques: From scalar diffusion-weighted imaging to diffusion tensor imaging and beyond. Radiographics 2006, 26, S205-S223. [CrossRef] [PubMed]

103. Van Everdingen, K.J.; van der Grond, J.; Kappelle, L.J.; Ramos, L.M.; Mali, W.P. Diffusion-weighted magnetic resonance imaging in acute stroke. Stroke 1998, 29, 1783-1790. [CrossRef] [PubMed]

104. Redgrave, J.N.E.; Coutts, S.B.; Schulz, U.G.; Briley, D.; Rothwell, P.M. Systematic review of associations between the presence of acute ischemic lesions on diffusion-weighted imaging and clinical predictors of early stroke risk after transient ischemic attack. Stroke 2007, 38, 1482-1488. [CrossRef] [PubMed]

105. Mascalchi, M.; Filippi, M.; Floris, R.; Fonda, C.; Gasparotti, R.; Villari, N. Diffusion-weighted MR of the brain: Methodology and clinical application. Radiol. Med. 2005, 109, 155-197. [PubMed]

106. Copen, W.A.; Schaefer, P.W.; Wu, O. MR perfusion imaging in acute ischemic stroke. Neuroimaging Clin. N. Am. 2011, 21, 259-283. [CrossRef] [PubMed]

107. Lacerda, S.; Law, M. Magnetic resonance perfusion and permeability imaging in brain tumors. Neuroimaging Clin. N. Am. 2009, 19, 527-557. [CrossRef] [PubMed]

108. Jackson, A.; O'Connor, J.; Thompson, G.; Mills, S. Magnetic resonance perfusion imaging in neuro-oncology. Cancer Imaging 2008, 8, 186-199. [CrossRef] [PubMed] 
109. Law, M.; Young, R.J.; Babb, J.S.; Peccerelli, N.; Chheang, S.; Gruber, M.L.; Miller, D.C.; Golfinos, J.G.; Zagzag, D.; Johnson, G. Gliomas: Predicting time to progression or survival with cerebral blood volume measurements at dynamic susceptibility-weighted contrast-enhanced perfusion MR imaging. Radiology 2008, 247, 490-498. [CrossRef] [PubMed]

110. Choi, S.H.; Jung, S.C.; Kim, K.W.; Lee, J.Y.; Choi, Y.; Park, S.H.; Kim, H.S. Perfusion MRI as the predictive/prognostic and pharmacodynamic biomarkers in recurrent malignant glioma treated with bevacizumab: A systematic review and a time-to-event meta-analysis. J. Neurooncol. 2016, 128, 185-194. [CrossRef] [PubMed]

111. Liu, C.; Li, W.; Tong, K.A.; Yeom, K.W.; Kuzminski, S. Susceptibility-weighted imaging and quantitative susceptibility mapping in the brain. J. Magn. Reson. Imaging 2015, 42, 23-41. [CrossRef] [PubMed]

112. Liu, S.; Buch, S.; Chen, Y.; Choi, H.-S.; Dai, Y.; Habib, C.; Hu, J.; Jung, J.Y.; Luo, Y.; Utriainen, D.; et al. Susceptibility-weighted imaging: Current status and future directions. NMR Biomed. 2016. [CrossRef] [PubMed]

113. Heyn, C.; Alcaide-Leon, P.; Bharatha, A.; Sussman, M.S.; Kucharczyk, W.; Mandell, D.M. Susceptibility-weighted Imaging in Neurovascular Disease. Top. Magn. Reson. Imaging 2016, 25, 63-71. [PubMed]

114. Di Ieva, A.; Lam, T.; Alcaide-Leon, P.; Bharatha, A.; Montanera, W.; Cusimano, M.D. Magnetic resonance susceptibility weighted imaging in neurosurgery: Current applications and future perspectives. J. Neurosurg. 2015, 123, 1463-1475. [CrossRef] [PubMed]

115. Deistung, A.; Schweser, F.; Reichenbach, J.R. Overview of quantitative susceptibility mapping. NMR Biomed. 2016. [CrossRef] [PubMed]

116. Li, W.; Liu, C.; Duong, T.Q.; van Zijl, P.C.M.; Li, X. Susceptibility tensor imaging (STI) of the brain. NMR Biomed. 2016. [CrossRef] [PubMed]

117. Reichenbach, J.R.; Schweser, F.; Serres, B.; Deistung, A. Quantitative Susceptibility Mapping: Concepts and Applications. Clin. Neuroradiol. 2015, 25, 225-230. [CrossRef] [PubMed]

118. Mikati, A.G.; Tan, H.; Shenkar, R.; Li, L.; Zhang, L.; Guo, X.; Larsson, H.B.; Shi, C.; Liu, T.; Wang, Y.; et al. Dynamic permeability and quantitative susceptibility: Related imaging biomarkers in cerebral cavernous malformations. Stroke 2014, 45, 598-601. [CrossRef] [PubMed]

119. Tan, H.; Liu, T.; Wu, Y.; Thacker, J.; Shenkar, R.; Mikati, A.G.; Shi, C.; Dykstra, C.; Wang, Y.; Prasad, P.V.; et al. Evaluation of iron content in human cerebral cavernous malformation using quantitative susceptibility mapping. Investig. Radiol. 2014, 49, 498-504. [CrossRef] [PubMed]

120. Chang, S.; Zhang, J.; Liu, T.; Tsiouris, A.J.; Shou, J.; Nguyen, T.; Leifer, D.; Wang, Y.; Kovanlikaya, I. Quantitative Susceptibility Mapping of Intracerebral Hemorrhages at Various Stages. J. Magn. Reson. Imaging 2016, 44, 420-425. [CrossRef] [PubMed]

121. Wang, S.; Lou, M.; Liu, T.; Cui, D.; Chen, X.; Wang, Y. Hematoma volume measurement in gradient echo MRI using quantitative susceptibility mapping. Stroke 2013, 44, 2315-2317. [CrossRef] [PubMed]

122. Chen, W.; Zhu, W.; Kovanlikaya, I.; Kovanlikaya, A.; Liu, T.; Wang, S.; Salustri, C.; Wang, Y. Intracranial calcifications and hemorrhages: Characterization with quantitative susceptibility mapping. Radiology 2014, 270, 496-505. [CrossRef] [PubMed]

123. Wei, H.; Xie, L.; Dibb, R.; Li, W.; Decker, K.; Zhang, Y.; Johnson, G.A.; Liu, C. Imaging whole-brain cytoarchitecture of mouse with MRI-based quantitative susceptibility mapping. Neuroimage 2016, 137, 107-115. [CrossRef] [PubMed]

124. Dieleman, N.; van der Kolk, A.G.; Zwanenburg, J.J.M.; Harteveld, A.A.; Biessels, G.J.; Luijten, P.R.; Hendrikse, J. Imaging intracranial vessel wall pathology with magnetic resonance imaging: Current prospects and future directions. Circulation 2014, 130, 192-201. [CrossRef] [PubMed]

125. Alexander, M.D.; Yuan, C.; Rutman, A.; Tirschwell, D.L.; Palagallo, G.; Gandhi, D.; Sekhar, L.N.; Mossa-Basha, M. High-resolution intracranial vessel wall imaging: Imaging beyond the lumen. J. Neurol. Neurosurg. Psychiatr. 2016, 87, 589-597. [CrossRef] [PubMed]

126. Mossa-Basha, M.; Alexander, M.; Gaddikeri, S.; Yuan, C.; Gandhi, D. Vessel wall imaging for intracranial vascular disease evaluation. J. Neurointerv. Surg. 2016. [CrossRef] [PubMed]

127. De Havenon, A.; Chung, L.; Park, M.; Mossa-Basha, M. Intracranial vessel wall MRI: A review of current indications and future applications. Neurovasc. Imaging 2016, 2. [CrossRef] 
128. Dieleman, N.; Yang, W.; Abrigo, J.M.; Chu, W.C.W.; van der Kolk, A.G.; Siero, J.C.W.; Wong, K.S.; Hendrikse, J.; Chen, X.Y. Magnetic Resonance Imaging of Plaque Morphology, Burden, and Distribution in Patients With Symptomatic Middle Cerebral Artery Stenosis. Stroke 2016, 47, 1797-1802. [CrossRef] [PubMed]

129. Jiang, Y.; Zhu, C.; Peng, W.; Degnan, A.J.; Chen, L.; Wang, X.; Liu, Q.; Wang, Y.; Xiang, Z.; Teng, Z.; et al. Ex Vivo imaging and plaque type classification of intracranial atherosclerotic plaque using high resolution MRI. Atherosclerosis 2016, 249, 10-16. [CrossRef] [PubMed]

130. Zhao, D.-L.; Deng, G.; Xie, B.; Ju, S.; Yang, M.; Chen, X.-H.; Teng, G.J. High-resolution MRI of the vessel wall in patients with symptomatic atherosclerotic stenosis of the middle cerebral artery. J. Clin. Neurosci. 2015, 22, 700-704. [CrossRef] [PubMed]

131. Mossa-Basha, M.; Hwang, W.D.; de Havenon, A.; Hippe, D.; Balu, N.; Becker, K.J.; Tirschwell, D.T.; Hatsukami, T.; Anzai, Y.; Yuan, C. Multicontrast high-resolution vessel wall magnetic resonance imaging and its value in differentiating intracranial vasculopathic processes. Stroke 2015, 46, 1567-1573. [CrossRef] [PubMed]

132. Zhu, X.-J.; Wang, W.; Liu, Z.-J. High-resolution Magnetic Resonance Vessel Wall Imaging for Intracranial Arterial Stenosis. Chin. Med. J. 2016, 129, 1363-1370. [PubMed]

133. Gounis, M.J.; van der Marel, K.; Marosfoi, M.; Mazzanti, M.L.; Clarençon, F.; Chueh, J.-Y.; Puri, A.S.; Bogdanov, A.A. Imaging Inflammation in Cerebrovascular Disease. Stroke 2015, 46, 2991-2997. [CrossRef] [PubMed]

134. Obusez, E.C.; Hui, F.; Hajj-Ali, R.A.; Cerejo, R.; Calabrese, L.H.; Hammad, T.; Jones, S.E. High-resolution MRI vessel wall imaging: Spatial and temporal patterns of reversible cerebral vasoconstriction syndrome and central nervous system vasculitis. AJNR Am. J. Neuroradiol. 2014, 35, 1527-1532. [CrossRef] [PubMed]

135. Matouk, C.C.; Cord, B.J.; Yeung, J.; Malhotra, A.; Johnson, M.H.; Minja, F.J. High-resolution Vessel Wall Magnetic Resonance Imaging in Intracranial Aneurysms and Brain Arteriovenous Malformations. Top. Magn. Reson. Imaging 2016, 25, 49-55. [PubMed]

136. Yuan, M.; Liu, Z.-Q.; Wang, Z.-Q.; Li, B.; Xu, L.-J.; Xiao, X.-L. High-resolution MR imaging of the arterial wall in moyamoya disease. Neurosci. Lett. 2015, 584, 77-82. [CrossRef] [PubMed]

137. Ryoo, S.; Cha, J.; Kim, S.J.; Choi, J.W.; Ki, C.-S.; Kim, K.H.; Jeon, P.; Kim, J.S.; Hong, S.C.; Bang, O.Y. High-resolution magnetic resonance wall imaging findings of Moyamoya disease. Stroke 2014, 45, 2457-2460. [CrossRef] [PubMed]

138. Edjlali, M.; Gentric, J.-C.; Régent-Rodriguez, C.; Trystram, D.; Hassen, W.B.; Lion, S.; Nataf, F.; Raymond, J.; Wieben, O.; Turski, P.; et al. Does aneurysmal wall enhancement on vessel wall MRI help to distinguish stable from unstable intracranial aneurysms? Stroke 2014, 45, 3704-3706. [CrossRef] [PubMed]

139. Matouk, C.C.; Mandell, D.M.; Gunel, M.; Bulsara, K.R.; Malhotra, A.; Hebert, R.; Johnson, M.H.; Mikulis, D.J.; Minja, F.J. Vessel wall magnetic resonance imaging identifies the site of rupture in patients with multiple intracranial aneurysms: Proof of principle. Neurosurgery 2013, 72, 492-496. [CrossRef] [PubMed]

140. Nagahata, S.; Nagahata, M.; Obara, M.; Kondo, R.; Minagawa, N.; Sato, S.; Sato, S.; Mouri, W.; Saito, S.; Kayama, T. Wall Enhancement of the Intracranial Aneurysms Revealed by Magnetic Resonance Vessel Wall Imaging Using Three-Dimensional Turbo Spin-Echo Sequence with Motion-Sensitized Driven-Equilibrium: A Sign of Ruptured Aneurysm? Clin. Neuroradiol. 2016, 26, 277-283. [CrossRef] [PubMed]

141. Obusez, E.C.; Jones, S.E.; Hui, F. Vessel wall MRI for suspected isolated basilar artery dissection. J. Clin. Neurosci. 2016, 27, 177-179. [CrossRef] [PubMed]

142. Ghoshhajra, B.; Engel, L.-C.; Gregory, T. MR Angiography. In Magnetic Resonance Angiography Basics to Future; InTech: Boston, MA, USA, 2012.

143. Ozsarlak, O.; van Goethem, J.W.; Maes, M.; Parizel, P.M. MR angiography of the intracranial vessels: Technical aspects and clinical applications. Neuroradiology 2004, 46, 955-972. [CrossRef] [PubMed]

144. Prince, M.R. Gadolinium-enhanced MR aortography. Radiology 1994, 191, 155-164. [CrossRef] [PubMed]

145. Riederer, S.J.; Haider, C.R.; Borisch, E.A.; Weavers, P.T.; Young, P.M. Recent advances in 3D time-resolved contrast-enhanced MR angiography. J. Magn. Reson. Imaging 2015, 42, 3-22. [CrossRef] [PubMed]

146. Nielsen, Y.W.; Thomsen, H.S. Contrast-enhanced peripheral MRA: Technique and contrast agents. Acta Radiol. 2012, 53, 769-777. [CrossRef] [PubMed]

147. Marchal, G.; Michiels, J.; Bosmans, H.; van Hecke, P. Contrast-enhanced MRA of the brain. J. Comput. Assist. Tomogr. 1992, 16, 25-29. [CrossRef] [PubMed] 
148. Sohn, C.-H.; Sevick, R.J.; Frayne, R. Contrast-enhanced MR angiography of the intracranial circulation. Magn. Reson. Imaging Clin. N. Am. 2003, 11, 599-614. [CrossRef]

149. Anzalone, N.; Scotti, R.; Iadanza, A. MR angiography of the carotid arteries and intracranial circulation: Advantage of a high relaxivity contrast agent. Neuroradiology 2006, 48, 9-17. [CrossRef] [PubMed]

150. Miyazaki, M.; Lee, V.S. Nonenhanced MR angiography. Radiology 2008, 248, 20-43. [CrossRef] [PubMed]

151. Wheaton, A.J.; Miyazaki, M. Non-contrast enhanced MR angiography: Physical principles. J. Magn. Reson. Imaging 2012, 36, 286-304. [CrossRef] [PubMed]

152. Neumann, J.-O.; Giese, H.; Nagel, A.M.; Biller, A.; Unterberg, A.; Meinzer, H.-P. MR Angiography at 7T to Visualize Cerebrovascular Territories. J. Neuroimaging 2016. [CrossRef] [PubMed]

153. Anzalone, N.; Tartaro, A. Intracranial MR Angiography. In Magnetic Resonance Angiography; Springer: Milan, Italy, 2005; pp. 103-138.

154. Bash, S.; Villablanca, J.P.; Jahan, R.; Duckwiler, G.; Tillis, M.; Kidwell, C.; Saver, J.; Sayre, J. Intracranial vascular stenosis and occlusive disease: Evaluation with $\mathrm{CT}$ angiography, MR angiography, and digital subtraction angiography. Am. J. Neuroradiol. 2005, 26, 1012-1021. [PubMed]

155. Cirillo, M.; Scomazzoni, F.; Cirillo, L.; Cadioli, M.; Simionato, F.; Iadanza, A.; Kirchin, M.; Righi, C.; Anzalone, N. Comparison of 3D TOF-MRA and 3D CE-MRA at 3T for imaging of intracranial aneurysms. Eur. J. Radiol. 2013, 82, e853-e859. [CrossRef] [PubMed]

156. Hadizadeh, D.R.; Falkenhausen von, M.; Gieseke, J.; Meyer, B.; Urbach, H.; Hoogeveen, R.; Schild, H.H.; Willinek, W.A. Cerebral arteriovenous malformation: Spetzler-Martin classification at subsecond-temporal-resolution four-dimensional MR angiography compared with that at DSA. Radiology 2008, 246, 205-213. [CrossRef] [PubMed]

157. Campeau, N.G.; Huston, J. Vascular disorders-magnetic resonance angiography: Brain vessels. Neuroimaging Clin. N. Am. 2012, 22, 207-233. [CrossRef] [PubMed]

158. Frayne, R.; Grist, T.M.; Swan, J.S.; Peters, D.C.; Korosec, F.R.; Mistretta, C.A. 3D MR DSA: Effects of injection protocol and image masking. J. Magn. Reson. Imaging 2000, 12, 476-487. [CrossRef]

159. Davis, B.; Royalty, K.; Kowarschik, M.; Rohkohl, C.; Oberstar, E.; Aagaard-Kienitz, B.; Niemann, D.; Ozkan, O.; Strother, C.; Mistretta, C. 4D digital subtraction angiography: Implementation and demonstration of feasibility. AJNR Am. J. Neuroradiol. 2013, 34, 1914-1921. [CrossRef] [PubMed]

160. Grist, T.M.; Mistretta, C.A.; Strother, C.M.; Turski, P.A. Time-resolved angiography: Past, present, and future. J. Magn. Reson. Imaging 2012, 36, 1273-1286. [CrossRef] [PubMed]

161. Mistretta, C.A.; Grist, T.M. X-ray digital subtraction angiography to magnetic resonance-digital subtraction angiography using three-dimensional TRICKS. Historical perspective and computer simulations: A review. Investig. Radiol. 1998, 33, 496-505. [CrossRef]

162. Harrington, D.P.; Boxt, L.M.; Murray, P.D. Digital subtraction angiography: Overview of technical principles. Am. J. Roentgenol. 1982, 139, 781-786. [CrossRef] [PubMed]

163. Stevens, J. Digital subtraction angiography. Clin. Radiol. 1989, 40, 325-326. [CrossRef]

164. Carmody, R.F.; Seeger, J.F. Intracranial applications of digital subtraction angiography. Crit. Rev. Diagn. Imaging 1984, 23, 1-40. [CrossRef] [PubMed]

165. Srinivasan, V.M.; Chintalapani, G.; Duckworth, E.A.M.; Kan, P. Application of 4-Dimensional Digital Subtraction Angiography for Dural Arteriovenous Fistulas. World Neurosurg. 2016, 96, 24-30. [CrossRef] [PubMed]

166. Wong, S.C.; Nawawi, O.; Ramli, N.; Abd Kadir, K.A. Benefits of 3D rotational DSA compared with 2D DSA in the evaluation of intracranial aneurysm. Acad. Radiol. 2012, 19, 701-707. [CrossRef] [PubMed]

167. Herzig, R.; Burval, S.; Krupka, B.; Vlachová, I.; Urbánek, K.; Mares, J. Comparison of ultrasonography, CT angiography, and digital subtraction angiography in severe carotid stenoses. Eur. J. Neurol. 2004, 11, 774-781. [CrossRef] [PubMed]

168. Hung, S.-C.; Liang, M.-L.; Lin, C.-F.; Lin, C.-J.; Guo, W.-Y.; Chang, F.-C.; Wong, T.T.; Chang, C.Y. New grading of moyamoya disease using color-coded parametric quantitative digital subtraction angiography. J. Chin. Med. Assoc. 2014, 77, 437-442. [CrossRef] [PubMed]

169. Wen, W.-L.; Fang, Y.-B.; Yang, P.-F.; Zhang, Y.-W.; Wu, Y.-N.; Shen, H.; Ge, J.J.; Xu, Y.; Hong, B.; Huang, Q.H.; et al. Parametric Digital Subtraction Angiography Imaging for the Objective Grading of Collateral Flow in Acute Middle Cerebral Artery Occlusion. World Neurosurg. 2016, 88, 119-125. [CrossRef] [PubMed] 
170. Aaslid, R.; Markwalder, T.M.; Nornes, H. Noninvasive transcranial Doppler ultrasound recording of flow velocity in basal cerebral arteries. J. Neurosurg. 1982, 57, 769-774. [CrossRef] [PubMed]

171. Naqvi, J.; Yap, K.H.; Ahmad, G.; Ghosh, J. Transcranial Doppler ultrasound: A review of the physical principles and major applications in critical care. Int. J. Vasc. Med. 2013, 2013, 629378. [CrossRef] [PubMed]

172. Topcuoglu, M.A. Transcranial Doppler ultrasound in neurovascular diseases: Diagnostic and therapeutic aspects. J. Neurochem. 2012, 123, 39-51. [CrossRef] [PubMed]

173. Bathala, L.; Mehndiratta, M.M.; Sharma, V.K. Transcranial doppler: Technique and common findings (Part 1). Ann. Indian Acad. Neurol. 2013, 16, 174-179. [CrossRef] [PubMed]

174. D'Andrea, A.; Conte, M.; Cavallaro, M.; Scarafile, R.; Riegler, L.; Cocchia, R.; Pezzullo, E.; Carbone, A.; Natale, F.; Santoro, G.; et al. Transcranial Doppler ultrasonography: From methodology to major clinical applications. World J. Cardiol. 2016, 8, 383-400. [CrossRef] [PubMed]

175. Sharma, A.K.; Bathala, L.; Batra, A.; Mehndiratta, M.M.; Sharma, V.K. Transcranial Doppler: Techniques and advanced applications: Part 2. Ann. Indian Acad. Neurol. 2016, 19, 102-107. [PubMed]

176. Zhang, Y.; Hong, H.; Cai, W. Photoacoustic imaging. Cold Spring Harb. Protoc. 2011. [CrossRef] [PubMed]

177. Maugh, T.H. Photoacoustic spectroscopy: New uses for an old technique. Science 1975, 188, 38-39. [CrossRef] [PubMed]

178. Beard, P. Biomedical photoacoustic imaging. Interface Focus 2011, 1, 602-631. [CrossRef] [PubMed]

179. Li, C.; Wang, L.V. Photoacoustic tomography and sensing in biomedicine. Phys. Med. Biol. 2009, 54, R59-R97. [CrossRef] [PubMed]

180. Wang, L.V.; Gao, L. Photoacoustic microscopy and computed tomography: From bench to bedside. Annu. Rev. Biomed. Eng. 2014, 16, 155-185. [CrossRef] [PubMed]

181. Nie, L.; Chen, X. Structural and functional photoacoustic molecular tomography aided by emerging contrast agents. Chem. Soc. Rev. 2014, 43, 7132-7170. [CrossRef] [PubMed]

182. Wang, X.; Ku, G.; Wegiel, M.A.; Bornhop, D.J.; Stoica, G.; Wang, L.V. Noninvasive photoacoustic angiography of animal brains in vivo with near-infrared light and an optical contrast agent. Opt. Lett. 2004, 29, 730-732. [CrossRef] [PubMed]

183. Xu, H.; Li, Q.; Wang, L.; He, Y.; Shi, J.; Tang, B.; Fan, C. Nanoscale optical probes for cellular imaging. Chem. Soc. Rev. 2014, 43, 2650-2661. [CrossRef] [PubMed]

184. Wang, D.; Wu, Y.; Xia, J. Review on photoacoustic imaging of the brain using nanoprobes. Neurophotonics 2016, 3, 010901. [CrossRef] [PubMed]

185. Filonov, G.S.; Krumholz, A.; Xia, J.; Yao, J.; Wang, L.V.; Verkhusha, V.V. Deep-tissue photoacoustic tomography of a genetically encoded near-infrared fluorescent probe. Angew. Chem. Int. Ed. Engl. 2012, 51, 1448-1451. [CrossRef] [PubMed]

186. Paproski, R.J.; Heinmiller, A.; Wachowicz, K.; Zemp, R.J. Multi-wavelength photoacoustic imaging of inducible tyrosinase reporter gene expression in xenograft tumors. Sci. Rep. 2014, 4, 5329. [CrossRef] [PubMed]

187. Xia, J.; Yao, J.; Wang, L.V. Photoacoustic tomography: Principles and advances. Electromagn. Waves 2014, 147, 1-22. [CrossRef]

188. Wang, L.V.; Yao, J. A practical guide to photoacoustic tomography in the life sciences. Nat. Methods 2016, 13, 627-638. [CrossRef] [PubMed]

189. Zhou, Y.; Yao, J.; Wang, L.V. Tutorial on photoacoustic tomography. J. Biomed. Opt. 2016, 21. [CrossRef] [PubMed]

190. Wang, L.V.; Hu, S. Photoacoustic tomography: In vivo imaging from organelles to organs. Science 2012, 335, 1458-1462. [CrossRef] [PubMed]

191. Hu, S.; Maslov, K.; Wang, L.V. Second-generation optical-resolution photoacoustic microscopy with improved sensitivity and speed. Opt. Lett. 2011, 36, 1134-1136. [CrossRef] [PubMed]

192. Zhang, H.F.; Maslov, K.; Stoica, G.; Wang, L.V. Functional photoacoustic microscopy for high-resolution and noninvasive in vivo imaging. Nat. Biotechnol. 2006, 24, 848-851. [CrossRef] [PubMed]

193. Xia, J.; Chatni, M.R.; Maslov, K.; Guo, Z.; Wang, K.; Anastasio, M.; Wang, L.V. Whole-body ring-shaped confocal photoacoustic computed tomography of small animals in vivo. J. Biomed. Opt. 2012, 17. [CrossRef] [PubMed]

194. Lin, L.; Xia, J.; Wong, T.T.W.; Li, L.; Wang, L.V. In vivo deep brain imaging of rats using oral-cavity illuminated photoacoustic computed tomography. J. Biomed. Opt. 2015, 20. [CrossRef] [PubMed] 
195. Yoon, T.-J.; Cho, Y.-S. Recent advances in photoacoustic endoscopy. World. J. Gastrointest. Endosc. 2013, 5, 534-539. [CrossRef] [PubMed]

196. Yao, J.; Wang, L.; Yang, J.-M.; Maslov, K.I.; Wong, T.T.W.; Li, L.; Huang, C.H.; Zou, J.; Wang, L.V. High-speed label-free functional photoacoustic microscopy of mouse brain in action. Nat. Methods. 2015, 12, 407-410. [CrossRef] [PubMed]

197. Nasiriavanaki, M.; Xia, J.; Wan, H.; Bauer, A.Q.; Culver, J.P.; Wang, L.V. High-resolution photoacoustic tomography of resting-state functional connectivity in the mouse brain. Proc. Natl. Acad. Sci. USA 2014, 111, 21-26. [PubMed]

198. Ning, B.; Sun, N.; Cao, R.; Chen, R.; Kirk Shung, K.; Hossack, J.A.; Lee, J.M.; Zhou, Q.; Hu, S. Ultrasound-aided Multi-parametric Photoacoustic Microscopy of the Mouse Brain. Sci. Rep. 2015, 5, 18775. [CrossRef] [PubMed]

199. Tang, J.; Dai, X.; Jiang, H. Wearable scanning photoacoustic brain imaging in behaving rats. J. Biophoton. 2016, 9, 570-575. [CrossRef] [PubMed]

200. Yao, J.; Wang, L.V. Photoacoustic Brain Imaging: From Microscopic to Macroscopic Scales. Neurophotonics 2014, 1. [CrossRef] [PubMed]

201. Kneipp, M.; Turner, J.; Hambauer, S.; Krieg, S.M.; Lehmberg, J.; Lindauer, U.; Razansky, D. Functional real-time optoacoustic imaging of middle cerebral artery occlusion in mice. PLoS ONE 2014, 9, e96118. [CrossRef] [PubMed]

202. Sakadžić, S.; Lee, J.; Boas, D.A.; Ayata, C. High-resolution in vivo optical imaging of stroke injury and repair. Brain Res. 2015, 1623, 174-192. [CrossRef] [PubMed]

203. Deng, Z.; Wang, Z.; Yang, X.; Luo, Q.; Gong, H. In vivo imaging of hemodynamics and oxygen metabolism in acute focal cerebral ischemic rats with laser speckle imaging and functional photoacoustic microscopy. J. Biomed. Opt. 2012, 17. [CrossRef] [PubMed]

204. Attia, A.B.E.; Ho, C.J.H.; Chandrasekharan, P.; Balasundaram, G.; Tay, H.C.; Burton, N.C.; Chuang, K.H.; Ntziachristos, V.; Olivo, M. Multispectral optoacoustic and MRI coregistration for molecular imaging of orthotopic model of human glioblastoma. J. Biophotonics 2016, 9, 701-708. [CrossRef] [PubMed]

205. Ku, G.; Wang, X.; Xie, X.; Stoica, G.; Wang, L.V. Imaging of tumor angiogenesis in rat brains in vivo by photoacoustic tomography. Appl. Opt. 2005, 44, 770-775. [CrossRef] [PubMed]

206. Fan, Q.; Cheng, K.; Yang, Z.; Zhang, R.; Yang, M.; Hu, X.; Ma, X.; Bu, L.; Lu, X.; Xiong, X.; et al. Perylene-diimide-based nanoparticles as highly efficient photoacoustic agents for deep brain tumor imaging in living mice. Adv. Mater. 2015, 27, 843-847. [CrossRef] [PubMed]

207. Xu, Z.; Zhu, Q.; Wang, L.V. In vivo photoacoustic tomography of mouse cerebral edema induced by cold injury. J. Biomed. Opt. 2011, 16. [CrossRef] [PubMed]

208. Tsytsarev, V.; Rao, B.; Maslov, K.I.; Li, L.; Wang, L.V. Photoacoustic and optical coherence tomography of epilepsy with high temporal and spatial resolution and dual optical contrasts. J. Neurosci. Methods. 2013, 216, 142-145. [CrossRef] [PubMed]

209. Yang, S.; Xing, D.; Lao, Y.; Yang, D.; Zeng, L.; Xiang, L.; Chen, W.R. Noninvasive monitoring of traumatic brain injury and post-traumatic rehabilitation with laser-induced photoacoustic imaging. Appl. Phys. Lett. 2007, 90, 243902. [CrossRef]

210. Guevara, E.; Berti, R.; Londono, I.; Xie, N.; Bellec, P.; Lesage, F.; Lodygensky, G.A. Imaging of an inflammatory injury in the newborn rat brain with photoacoustic tomography. PLoS ONE 2013, 8, e83045. [CrossRef] [PubMed]

211. Nie, L.; Cai, X.; Maslov, K.; Garcia-Uribe, A.; Anastasio, M.A.; Wang, L.V. Photoacoustic tomography through a whole adult human skull with a photon recycler. J. Biomed. Opt. 2012, 17. [CrossRef] [PubMed]

212. Nie, L.; Guo, Z.; Wang, L.V. Photoacoustic tomography of monkey brain using virtual point ultrasonic transducers. J. Biomed. Opt. 2011, 16. [CrossRef] [PubMed]

213. Huang, C.; Nie, L.; Schoonover, R.W.; Guo, Z.; Schirra, C.O.; Anastasio, M.A.; Wang, L.V. Aberration correction for transcranial photoacoustic tomography of primates employing adjunct image data. J. Biomed. Opt. 2012, 17. [CrossRef] [PubMed]

214. Obermeier, B.; Daneman, R.; Ransohoff, R.M. Development, maintenance and disruption of the blood-brain barrier. Nat. Med. 2013, 19, 1584-1596. [CrossRef] [PubMed]

215. Daneman, R.; Prat, A. The Blood-Brain Barrier. Cold Spring Harb. Perspect. Biol. 2015, 7, a020412. [CrossRef] [PubMed] 
216. Zhao, Z.; Nelson, A.R.; Betsholtz, C.; Zlokovic, B.V. Establishment and Dysfunction of the Blood-Brain Barrier. Cell 2015, 163, 1064-1078. [CrossRef] [PubMed]

217. Rosenberg, G.A. Neurological diseases in relation to the blood-brain barrier. J. Cereb. Blood Flow Metab. 2012, 32, 1139-1151. [CrossRef] [PubMed]

218. Palmer, A.M. The role of the blood-CNS barrier in CNS disorders and their treatment. Neurobiol. Dis. 2010, 37, 3-12. [CrossRef] [PubMed]

219. Winkler, E.A.; Nishida, Y.; Sagare, A.P.; Rege, S.V.; Bell, R.D.; Perlmutter, D.; Sengillo, J.D.; Hillman, S.; Kong, P.; Nelson, A.R.; et al. GLUT1 reductions exacerbate Alzheimer's disease vasculo-neuronal dysfunction and degeneration. Nat. Neurosci. 2015, 18, 521-530. [CrossRef] [PubMed]

220. Nguyen, L.N.; Ma, D.; Shui, G.; Wong, P.; Cazenave-Gassiot, A.; Zhang, X.; Wenk, M.R.; Goh, E.L.; Silver, D.L. Mfsd2a is a transporter for the essential omega-3 fatty acid docosahexaenoic acid. Nature 2014, 509, 503-506. [CrossRef] [PubMed]

221. Ben-Zvi, A.; Lacoste, B.; Kur, E.; Andreone, B.J.; Mayshar, Y.; Yan, H.; Gu, C. Mfsd2a is critical for the formation and function of the blood-brain barrier. Nature 2014, 509, 507-511. [CrossRef] [PubMed]

222. Luissint, A.-C.; Artus, C.; Glacial, F.; Ganeshamoorthy, K.; Couraud, P.-O. Tight junctions at the blood brain barrier: Physiological architecture and disease-associated dysregulation. Fluids Barriers CNS 2012, 9. [CrossRef] [PubMed]

223. O’Driscoll, M.C.; Daly, S.B.; Urquhart, J.E.; Black, G.C.M.; Pilz, D.T.; Brockmann, K.; McEntagart, M.; Abdel-Salam, G.; Zaki, M.; Wolf, N.I.; et al. Recessive mutations in the gene encoding the tight junction protein occludin cause band-like calcification with simplified gyration and polymicrogyria. Am. J. Hum. Genet. 2010, 87, 354-364. [CrossRef] [PubMed]

224. Woodfin, A.; Voisin, M.-B.; Beyrau, M.; Colom, B.; Caille, D.; Diapouli, F.-M.; Nash, G.B.; Chavakis, T.; Albelda, S.M.; Rainger, G.E.; et al. The junctional adhesion molecule JAM-C regulates polarized transendothelial migration of neutrophils in vivo. Nat. Immunol. 2011, 12, 761-769. [CrossRef] [PubMed]

225. Heye, A.K.; Culling, R.D.; Valdés Hernández, M.D.C.; Thrippleton, M.J.; Wardlaw, J.M. Assessment of blood-brain barrier disruption using dynamic contrast-enhanced MRI. A systematic review. Neuroimage Clin. 2014, 6, 262-274. [CrossRef] [PubMed]

226. Taheri, S.; Gasparovic, C.; Shah, N.J.; Rosenberg, G.A. Quantitative measurement of blood-brain barrier permeability in human using dynamic contrast-enhanced MRI with fast T1 mapping. Magn. Reson. Med. 2011, 65, 1036-1042. [CrossRef] [PubMed]

227. Sourbron, S.; Ingrisch, M.; Siefert, A.; Reiser, M.; Herrmann, K. Quantification of cerebral blood flow, cerebral blood volume, and blood-brain-barrier leakage with DCE-MRI. Magn. Reson. Med. 2009, 62, 205-217. [CrossRef] [PubMed]

228. Veksler, R.; Shelef, I.; Friedman, A. Blood-brain barrier imaging in human neuropathologies. Arch. Med. Res. 2014, 45, 646-652. [CrossRef] [PubMed]

229. Li, W.; Long, J.A.; Watts, L.T.; Jiang, Z.; Shen, Q.; Li, Y.; Duong, T.Q. A quantitative MRI method for imaging blood-brain barrier leakage in experimental traumatic brain injury. PLoS ONE 2014, 9, e114173. [CrossRef] [PubMed]

230. Taheri, S.; Gasparovic, C.; Huisa, B.N.; Adair, J.C.; Edmonds, E.; Prestopnik, J.; Grossetete, M.; Shah, N.J.; Wills, J.; Qualls, C.; et al. Blood-brain barrier permeability abnormalities in vascular cognitive impairment. Stroke 2011, 42, 2158-2163. [CrossRef] [PubMed]

231. Cramer, S.P.; Larsson, H.B.W. Accurate determination of blood-brain barrier permeability using dynamic contrast-enhanced T1-weighted MRI: A simulation and in vivo study on healthy subjects and multiple sclerosis patients. J. Cereb. Blood Flow Metab. 2014, 34, 1655-1665. [CrossRef] [PubMed]

232. Van de Haar, H.J.; Jansen, J.F.A.; van Osch, M.J.P.; van Buchem, M.A.; Muller, M.; Wong, S.M.; Hofman, P.A.; Burgmans, S.; Verhey, F.R.; Backes, W.H. Neurovascular unit impairment in early Alzheimer's disease measured with magnetic resonance imaging. Neurobiol. Aging 2016, 45, 190-196. [CrossRef] [PubMed]

233. Jain, R. Measurements of tumor vascular leakiness using DCE in brain tumors: Clinical applications. NMR Biomed. 2013, 26, 1042-1049. [CrossRef] [PubMed]

234. Merali, Z.; Wong, T.; Leung, J.; Gao, M.M.; Mikulis, D.; Kassner, A. Dynamic contrast-enhanced MRI and CT provide comparable measurement of blood-brain barrier permeability in a rodent stroke model. Magn. Reson. Imaging. 2015, 33, 1007-1012. [CrossRef] [PubMed] 
235. Sorbara, C.; Misgeld, T.; Kerschensteiner, M. In vivo imaging of the diseased nervous system: An update. Curr. Pharm. Des. 2012, 18, 4465-4470. [CrossRef] [PubMed]

236. Laviña, B.; Gaengel, K. New imaging methods and tools to study vascular biology. Curr. Opin. Hematol. 2015, 22, 258-266. [CrossRef] [PubMed]

237. Aswendt, M.; Schwarz, M.; Abdelmoula, W.M.; Dijkstra, J.; Dedeurwaerdere, S. Whole-Brain Microscopy Meets in Vivo Neuroimaging: Techniques, Benefits, and Limitations. Mol. Imaging Biol. 2016, 1-9. [CrossRef] [PubMed]

238. Yang, B.; Treweek, J.B.; Kulkarni, R.P.; Deverman, B.E.; Chen, C.-K.; Lubeck, E.; Shah, S.; Cai, L.; Gradinaru, V. Single-cell phenotyping within transparent intact tissue through whole-body clearing. Cell 2014, 158, 945-958. [CrossRef] [PubMed]

239. Silvestri, L.; Costantini, I.; Sacconi, L.; Pavone, F.S. Clearing of fixed tissue: A review from a microscopist's perspective. J. Biomed. Opt. 2016, 21. [CrossRef] [PubMed]

240. Richardson, D.S.; Lichtman, J.W. Clarifying Tissue Clearing. Cell 2015, 162, 246-257. [CrossRef] [PubMed]

241. Schuermann, A.; Helker, C.S.M.; Herzog, W. Angiogenesis in zebrafish. Semin. Cell Dev. Biol. 2014, 31, 106-114. [CrossRef] [PubMed]

242. Wilkinson, R.N.; van Eeden, F.J.M. The zebrafish as a model of vascular development and disease. Prog. Mol. Biol. Transl. Sci. 2014, 124, 93-122. [PubMed]

243. Larina, I.V.; Shen, W.; Kelly, O.G.; Hadjantonakis, A.-K.; Baron, M.H.; Dickinson, M.E. A Membrane Associated mCherry Fluorescent Reporter Line for Studying Vascular Remodeling and Cardiac Function during Murine Embryonic Development. Anat. Rec. 2009, 292, 333-341. [CrossRef] [PubMed]

244. Fraser, S.T.; Hadjantonakis, A.-K.; Sahr, K.E.; Willey, S.; Kelly, O.G.; Jones, E.A.V.; Dickinson, M.E.; Baron, M.H. Using a histone yellow fluorescent protein fusion for tagging and tracking endothelial cells in ES cells and mice. Genesis 2005, 42, 162-171. [CrossRef] [PubMed]

245. Ema, M.; Takahashi, S.; Rossant, J. Deletion of the selection cassette, but not cis-acting elements, in targeted Flk1-lacZ allele reveals Flk1 expression in multipotent mesodermal progenitors. Blood 2006, 107, 111-117. [CrossRef] [PubMed]

246. Ishitobi, H.; Matsumoto, K.; Azami, T.; Itoh, F.; Itoh, S.; Takahashi, S.; Ema, M. Flk1-GFP BAC Tg mice: An animal model for the study of blood vessel development. Exp. Anim. 2010, 59, 615-622. [CrossRef] [PubMed]

247. Matsumoto, K.; Azami, T.; Otsu, A.; Takase, H.; Ishitobi, H.; Tanaka, J.; Miwa, Y.; Takahashi, S.; Ema, M. Study of normal and pathological blood vessel morphogenesis in Flt1-tdsRed BAC Tg mice. Genesis 2012, 50, 561-571. [CrossRef] [PubMed]

248. Motoike, T.; Loughna, S.; Perens, E.; Roman, B.L.; Liao, W.; Chau, T.C.; Richardson, C.D.; Kawate, T.; Kuno, J.; Weinstein, B.M.; et al. Universal GFP reporter for the study of vascular development. Genesis 2000, 28, 75-81. [CrossRef]

249. Davy, A.; Bush, J.O.; Soriano, P. Inhibition of gap junction communication at ectopic Eph/ephrin boundaries underlies craniofrontonasal syndrome. PLoS Biol. 2006, 4, e315. [CrossRef] [PubMed]

250. Laviña, B.; Gaengel, K.; Castro, M. New transgenic reporter mouse line: New tool to study vascular biology and dynamics. In Presented at the Endothelial Cell Phenotypes in Health \& Disease, Gordon Conference, Girona, Spain, 6-11 July 2014.

251. Knowland, D.; Arac, A.; Sekiguchi, K.J.; Hsu, M.; Lutz, S.E.; Perrino, J.; Steinberg, G.K.; Barres, B.A.; Nimmerjahn, A.; Agalliu, D. Stepwise recruitment of transcellular and paracellular pathways underlies blood-brain barrier breakdown in stroke. Neuron 2014, 82, 603-617. [CrossRef] [PubMed]

252. Winderlich, M.; Keller, L.; Cagna, G.; Broermann, A.; Kamenyeva, O.; Kiefer, F.; Deutsch, U.; Nottebaum, A.F.; Vestweber, D. VE-PTP controls blood vessel development by balancing Tie-2 activity. J. Cell Biol. 2009, 185, 657-671. [CrossRef] [PubMed]

253. Hägerling, R.; Pollmann, C.; Kremer, L.; Andresen, V.; Kiefer, F. Intravital two-photon microscopy of lymphatic vessel development and function using a transgenic Prox1 promoter-directed mOrange2 reporter mouse. Biochem. Soc. Trans. 2011, 39, 1674-1681. [CrossRef] [PubMed]

254. Choi, I.; Chung, H.K.; Ramu, S.; Lee, H.N.; Kim, K.E.; Lee, S.; Yoo, J.; Choi, D.; Lee, Y.S.; Aguilar, B.; et al. Visualization of lymphatic vessels by Prox1-promoter directed GFP reporter in a bacterial artificial chromosome-based transgenic mouse. Blood 2011, 117, 362-365. [CrossRef] [PubMed] 
255. Truman, L.A.; Bentley, K.L.; Smith, E.C.; Massaro, S.A. ProxTom lymphatic vessel reporter mice reveal Prox1 expression in the adrenal medulla, megakaryocytes, and platelets. Am. J. Pathol. 2012, 180, 1715-1725. [CrossRef] [PubMed]

256. Martínez-Corral, I.; Olmeda, D. In vivo imaging of lymphatic vessels in development, wound healing, inflammation, and tumor metastasis. Proc. Natl. Acad. Sci. USA 2012, 109, 6223-6228. [CrossRef] [PubMed]

257. Calvo, C.-F.; Fontaine, R.H.; Soueid, J.; Tammela, T.; Mäkinen, T.; Alfaro-Cervello, C.; Bonnaud, F.; Miguez, A.; Benhaim, L.; Xu, Y.; et al. Vascular endothelial growth factor receptor 3 directly regulates murine neurogenesis. Genes Dev. 2011, 25, 831-844. [CrossRef] [PubMed]

258. Sevick-Muraca, E.M.; Kwon, S.; Rasmussen, J.C. Emerging lymphatic imaging technologies for mouse and man. J. Clin. Investig. 2014, 124, 905-914. [CrossRef] [PubMed]

259. Zhu, X.; Bergles, D.E.; Nishiyama, A. NG2 cells generate both oligodendrocytes and gray matter astrocytes. Development 2008, 135, 145-157. [CrossRef] [PubMed]

260. Gong, S.; Zheng, C.; Doughty, M.L.; Losos, K.; Didkovsky, N.; Schambra, U.B.; Nowak, N.J.; Joyner, A.; Leblanc, G.; Hatten, M.E.; et al. A gene expression atlas of the central nervous system based on bacterial artificial chromosomes. Nature 2003, 425, 917-925. [CrossRef] [PubMed]

261. Hall, C.N.; Reynell, C.; Gesslein, B.; Hamilton, N.B.; Mishra, A.; Sutherland, B.A.; O'Farrell, F.M.; Buchan, A.M.; Lauritzen, M.; Attwell, D. Capillary pericytes regulate cerebral blood flow in health and disease. Nature 2014, 508, 55-60. [CrossRef] [PubMed]

262. Riedl, J.; Flynn, K.C.; Raducanu, A.; Gärtner, F.; Beck, G.; Bösl, M.; Bradke, F.; Massberg, S.; Aszodi, A.; Sixt, M.; et al. Lifeact mice for studying F-actin dynamics. Nat. Methods 2010, 7, 168-169. [CrossRef] [PubMed]

263. Fraccaroli, A.; Franco, C.A.; Rognoni, E.; Neto, F.; Rehberg, M.; Aszodi, A.; Wedlich-Söldner, R.; Pohl, U.; Gerhardt, H.; Montanez, E. Visualization of endothelial actin cytoskeleton in the mouse retina. PLoS ONE 2012, 7, e47488. [CrossRef] [PubMed]

264. Pickles, S.; Cadieux-Dion, M.; Alvarez, J.I.; Lécuyer, M.-A.; Peyrard, S.L.; Destroismaisons, L.; St-Onge, L.; Terouz, S.; Cossette, P.; Prat, A.; et al. Endo-MitoEGFP mice: A novel transgenic mouse with fluorescently marked mitochondria in microvascular endothelial cells. PLoS ONE 2013, 8, e74603. [CrossRef] [PubMed]

265. Abe, T.; Fujimori, T. Reporter mouse lines for fluorescence imaging. Dev. Growth Differ. 2013, 55, $390-405$. [CrossRef] [PubMed]

266. Condie, B.G. The untapped potential of the GENSAT mice-A valuable resource for developmental biology. Genesis 2016, 54, 245-256. [CrossRef] [PubMed]

267. Raichle, M.E. A brief history of human brain mapping. Trends Neurosci. 2009, 32, 118-126. [CrossRef] [PubMed]

268. Nowinski, W.L. Usefulness of brain atlases in neuroradiology: Current status and future potential. Neuroradiol. J. 2016, 29, 260-268. [CrossRef] [PubMed]

269. Amunts, K.; Zilles, K. Architectonic Mapping of the Human Brain beyond Brodmann. Neuron 2015, 88, 1086-1107. [CrossRef] [PubMed]

270. Grillner, S.; Ip, N.; Koch, C.; Koroshetz, W.; Okano, H.; Polachek, M.; Poo, M.M.; Sejnowski, T.J. Worldwide initiatives to advance brain research. Nat. Neurosci. 2016, 19, 1118-1122. [CrossRef] [PubMed]

271. Lein, E.S.; Hawrylycz, M.J.; Ao, N.; Ayres, M.; Bensinger, A.; Bernard, A.; Boe, A.F.; Boguski, M.S.; Brockway, K.S.; Byrnes, E.J.; et al. Genome-wide atlas of gene expression in the adult mouse brain. Nature 2007, 445, 168-176. [CrossRef] [PubMed]

272. Hawrylycz, M.J.; Lein, E.S.; Guillozet-Bongaarts, A.L.; Shen, E.H.; Ng, L.; Miller, J.A.; van de Lagemaat, L.N.; Smith, K.A.; Ebbert, A.; Riley, Z.L.; et al. An anatomically comprehensive atlas of the adult human brain transcriptome. Nature 2012, 489, 391-399. [CrossRef] [PubMed]

273. Miller, J.A.; Ding, S.-L.; Sunkin, S.M.; Smith, K.A.; Ng, L.; Szafer, A.; Ebbert, A.; Riley, Z.L.; Royall, J.J.; Aiona, K.; et al. Transcriptional landscape of the prenatal human brain. Nature 2014, 508, 199-206. [CrossRef] [PubMed]

274. Bakken, T.E.; Miller, J.A.; Ding, S.-L.; Sunkin, S.M.; Smith, K.A.; Ng, L.; Szafer, A.; Dalley, R.A.; Royall, J.J.; Lemon, T.; et al. A comprehensive transcriptional map of primate brain development. Nature 2016, 535, 367-375. [CrossRef] [PubMed]

275. Shen, E.H.; Overly, C.C.; Jones, A.R. The Allen Human Brain Atlas: Comprehensive gene expression mapping of the human brain. Trends Neurosci. 2012, 35, 711-714. [CrossRef] [PubMed] 
276. Sunkin, S.M.; Ng, L.; Lau, C.; Dolbeare, T.; Gilbert, T.L.; Thompson, C.L.; Hawrylycz, M.; Dang, C. Allen Brain Atlas: An integrated spatio-temporal portal for exploring the central nervous system. Nucleic Acids Res. 2013, 41, D996-D1008. [CrossRef] [PubMed]

277. Bakker, R.; Tiesinga, P.; Kötter, R. The Scalable Brain Atlas: Instant Web-Based Access to Public Brain Atlases and Related Content. Neuroinformatics 2015, 13, 353-366. [CrossRef] [PubMed]

278. Van Essen, D.C.; Ugurbil, K.; Auerbach, E.; Barch, D.; Behrens, T.E.J.; Bucholz, R.; Chang, A.; Chen, L.; Corbetta, M.; Curtiss, S.W.; et al. The Human Connectome Project: A data acquisition perspective. Neuroimage 2012, 62, 2222-2231. [CrossRef] [PubMed]

279. Glasser, M.F.; Smith, S.M.; Marcus, D.S.; Andersson, J.L.R.; Auerbach, E.J.; Behrens, T.E.J.; Coalson, T.S.; Harms, M.P.; Jenkinson, M.; Moeller, S.; et al. The Human Connectome Project's neuroimaging approach. Nat. Neurosci. 2016, 19, 1175-1187. [CrossRef] [PubMed]

280. Ugurbil, K.; Xu, J.; Auerbach, E.J.; Moeller, S.; Vu, A.T.; Duarte-Carvajalino, J.M.; Lenglet, C.; Wu, X.; Schmitter, S.; van de Moorte, P.F.; et al. Pushing spatial and temporal resolution for functional and diffusion MRI in the Human Connectome Project. Neuroimage 2013, 80, 80-104. [CrossRef] [PubMed]

281. Glasser, M.F.; Coalson, T.S.; Robinson, E.C.; Hacker, C.D.; Harwell, J.; Yacoub, E.; Ugurbil, K.; Andersson, J.; Beckmann, C.F.; Jenkinson, M.; et al. A multi-modal parcellation of human cerebral cortex. Nature 2016, 536, 171-178. [CrossRef] [PubMed]

282. Amunts, K.; Lepage, C.; Borgeat, L.; Mohlberg, H.; Dickscheid, T.; Rousseau, M.-É.; Bludau, S.; Bazin, P.-L.; Lewis, L.B.; Oros-Peusquens, A.-M.; et al. BigBrain: An Ultrahigh-Resolution 3D Human Brain Model. Science 2013, 340, 1472-1475. [CrossRef] [PubMed]

283. Mohlberg, H.; Eickhoff, S.B.; Schleicher, A.; Zilles, K.; Amunts, K. A New Processing Pipeline and Release of Cytoarchitectonic Probabilistic Maps_JuBrain; OHBM: Beijing, China, 2012.

284. Vidoni, E.D. The Whole Brain Atlas. J. Neurol. Phys. Ther. 2012, 36, 108. [CrossRef]

285. Fan, L.; Li, H.; Zhuo, J.; Zhang, Y.; Wang, J.; Chen, L.; Yang, Z.; Chu, C.; Xie, S.; Laird, A.R.; et al. The Human Brainnetome Atlas: A New Brain Atlas Based on Connectional Architecture. Cereb. Cortex 2016, 26, 3508-3526. [CrossRef] [PubMed]

286. Gousias, I.S.; Edwards, A.D.; Rutherford, M.A.; Counsell, S.J.; Hajnal, J.V.; Rueckert, D.; Hammers, A. Magnetic resonance imaging of the newborn brain: Manual segmentation of labelled atlases in term-born and preterm infants. Neuroimage 2012, 62, 1499-1509. [CrossRef] [PubMed]

287. Kuklisova-Murgasova, M.; Aljabar, P.; Srinivasan, L.; Counsell, S.J.; Doria, V.; Serag, A.; Gousias, I.S.; Boardman, J.P.; Rutherford, M.A.; Edwards, A.D.; et al. A dynamic 4D probabilistic atlas of the developing brain. Neuroimage 2011, 54, 2750-2763. [CrossRef] [PubMed]

288. Hammers, A.; Allom, R.; Koepp, M.J.; Free, S.L.; Myers, R.; Lemieux, L.; Mitchell, T.N.; Brooks, D.J.; Duncan, J.S. Three-dimensional maximum probability atlas of the human brain, with particular reference to the temporal lobe. Hum. Brain Mapp. 2003, 19, 224-247. [CrossRef] [PubMed]

289. Jenkinson, M.; Beckmann, C.F.; Behrens, T.E.J.; Woolrich, M.W.; Smith, S.M. FSL. Neuroimage 2012, 62, $782-790$. [CrossRef] [PubMed]

290. MacKenzie-Graham, A.; Jones, E.S.; Shattuck, D.W.; Dinov, I.D.; Bota, M.; Toga, A.W. The informatics of a C57BL/6J mouse brain atlas. Neuroinformatics 2003, 1, 397-410. [CrossRef]

291. Randlett, O.; Wee, C.L.; Naumann, E.A.; Nnaemeka, O.; Schoppik, D.; Fitzgerald, J.E.; Portugues, R.; Lacoste, A.M.; Riegler, C.; Engert, F.; et al. Whole-brain activity mapping onto a zebrafish brain atlas. Nat. Methods. 2015, 12, 1039-1046. [CrossRef] [PubMed]

292. Milyaev, N.; Osumi-Sutherland, D.; Reeve, S.; Burton, N.; Baldock, R.A.; Armstrong, J.D. The Virtual Fly Brain browser and query interface. Bioinformatics 2012, 28, 411-415. [CrossRef] [PubMed]

293. Mai, J.K.; Majtanik, M.; Paxinos, G. Atlas of the Human Brain; Academic Press: Cambridge, MA, USA, 2015.

(C) 2016 by the author; licensee MDPI, Basel, Switzerland. This article is an open access article distributed under the terms and conditions of the Creative Commons Attribution (CC-BY) license (http:/ / creativecommons.org/licenses/by/4.0/). 